Article

\title{
Innovative Finance, Technological Adaptation and SMEs Sustainability: The Mediating Role of Government Support during COVID-19 Pandemic
}

\author{
Ganlin Pu ${ }^{1}$, Md. Qamruzzaman ${ }^{2, *}$, Ahmed Muneeb Mehta ${ }^{3} \mathbb{D}$, Farah Naz Naqvi ${ }^{3}$ and Salma Karim ${ }^{2}(\mathbb{D}$ \\ 1 School of Economics and Management, Wenzhou University of Technology, Wenzhou 325035, China; \\ chengy51499@163.com \\ 2 School of Business and Economics, United International University, Dhaka 1212, Bangladesh; \\ ska@bus.uiu.ac.bd \\ 3 Hailey College of Banking and Finance (HCBF), University of the Punjab, Lahore 5400, Pakistan; \\ ahmedmehta@puhcbf.edu.pk (A.M.M.); farah.n.naqvi@puhcbf.edu.pk (F.N.N.) \\ * Correspondence: qamruzzaman@bus.uiu.ac.bd or zaman_wut16@yahoo.com; Tel.: +880-1-718-612-983
}

Citation: Pu, G.; Qamruzzaman, M.; Mehta, A.M.; Naqvi, F.N.; Karim, S. Innovative Finance, Technological Adaptation and SMEs Sustainability: The Mediating Role of Government Support during COVID-19 Pandemic. Sustainability 2021, 13, 9218. https:// doi.org/10.3390/su13169218

Academic Editor: Ki-Hoon Lee

Received: 25 July 2021

Accepted: 13 August 2021

Published: 17 August 2021

Publisher's Note: MDPI stays neutral with regard to jurisdictional claims in published maps and institutional affiliations.

Copyright: (C) 2021 by the authors Licensee MDPI, Basel, Switzerland. This article is an open access article distributed under the terms and conditions of the Creative Commons Attribution (CC BY) license (https:// creativecommons.org/licenses/by/ $4.0 /)$.

\begin{abstract}
Small and medium enterprises (SMEs) survival is critical for economic sustainability due to the multifaceted role of the economy. Thus, halting SMEs operation hurts the aggregate economy. During the present pandemic, SMEs' sustainability in Bangladesh is under-challenged because of limited market demand, supply constraints, financial incapacity, and capital restrictions. However, with the concerted effort from firms and the government, SME's have been trying to reestablish from the unforeseen consequence by capitalizing on innovation, skills, and economic resources. The motivation of the study is to gauge the impact of innovative finance, technological adaptation, and the government's role on SMEs' sustainability during the COVID-19 pandemic in Bangladesh. As a study sample, 2000 SMEs were considered for data collection through a structured questionnaire from 10 December 2020, to 28 January 2021. A sample of 1895 SMEs was returned with their responses. However, after a careful data cleaning procedure, only a sample of 1395 (69.75\%) responses was found suitable for study. The study applied structural equation modelling to explore causal effects and test the proposed hypothesis for the hypnotized model, i.e., more precisely, to explore the direct effects of technology adaptation and innovative finance and indirect effects through government support on SMEs. Study findings revealed that SMEs' sustainability positively accelerates by applying innovative finance and integration of technological adaptation. In contrast, the mediating role of government was also established with indirect assessment. Study findings suggest that policy formulation and implementation must be initiated, focusing on effective online financial services, settling business transactions, and integrating IT advancements in operation.
\end{abstract}

Keywords: SMEs sustainability; innovative finance; technological adaptation; government role; SEM; COVID-19

\section{Introduction}

The COVID-19 pandemic is an unexpected worldwide epidemic that has brought chaos to the economy and essentially halted trade with extreme implications for sustainable businesses and society. Businesses have been forced to develop new and imaginative solutions to the world's most pressing problems due to the COVID-19 pandemic. Given the COVID-19 epidemic, small businesses (SMEs) have faced substantial difficulties consisting of both financial and non-financial events. Therefore, firms are unable to perform the ordinary course of business transactions [1,2]. The potential impact of COVID-19 on the economy is a broad discussion worldwide and expecting unanticipated consequences in aggregated output, unemployment, and poverty in Bangladesh is not an exception. Furthermore, McCloskey and Heymann [3] argued that the economy might apprehend economic sluggishness due to supply chain disruption, trade discontinuation, and limited 
market demand. Similar to other nations, Bangladesh's economy has already experienced severe and adverse effects in every corner.

Nonetheless, every economic sector has been severely affected, but profound effects are observed in SMEs. In most economies, SMEs play essential roles in driving growth, creating jobs, and opening new markets for sustainable development through domestic trade liberalization [4]. However, SMEs contributing to economic development have been challenged with the emergence of economic and financial crises. According to Runyan [5], SMEs are most seriously harmed in crises due to their lower knowledge levels, more susceptibility, greater reliance on government and local authorities, and greater financial reliance on owners. Moreover, Le et al. [6] revealed that the present pandemic had created discomfort for SMEs by exacerbating financial obligations such as credit payments to financial institutions, inventory shortages, and operational expenditures. Countries experiencing severe economic hardship have also been punished by the outbreak of COVID-19 due to the prolonged lockout imposed by either a partial or complete suspension. All economic operations have resulted in the most severe consequences for low-income citizens who have lost jobs and have limited access to food and social safety net services.

Small and medium enterprises' survival and contribution to the aggregate economy are critical for achieving sustainable goals, although numerous constraints prevent them from scaling up optimally [7]. For the question of survival, government, policymakers, credit disbursing agencies, and SMEs themselves have persistently sought methods to eliminate the unprecedented effects on their business units. When it comes to small company operations, owners are concerned. This, including unemployment creation, social security imbalance, financial activities disruption, and aggregate production, have had significant impacts on society [8].

The worldwide health crisis, which began in 2020, influenced enterprises of all sizes and sectors; however, certain sectors have shown resilience or discovered a new operational niche; most SMEs in the services sector found themselves in "new normal" operating settings [9]. The pandemic's negative impacts have been documented in various areas, including economic, political, social, and psychological consequences [10]. To stop the virus from spreading, many countries have instituted social segregation and limited business operations. Lockdowns, lower consumption, community closures, and company closures have all existed due to this. Many economists consider this epidemic as a metaphorical "black swan" event, defined as "an unexpected, unanticipated occurrence of tremendous importance and severe effects that profoundly transforms the political and economic landscape that leads to business failure" [11].

The COVID-19 pandemic is having a remarkable effect on SMEs' profitability and long-term viability; furthermore, the current situation has opened up a new channel for analyzing SMEs' adaptability and performance [12,13], reduction of financial constraints [14], and augmenting productivity [15]. Several studies have recommended that strategic resources support, such as technology integration, effective financial intermediation, and government incentives, are essential in improving their chances of survival during pandemics [16-18]. Referring to technological integration impact SMEs, a growing number of researchers have advocated the positive linkage between technology adaptation and sustainability [19-21]. This implies that operational efficiency enables SMEs to reap the benefits of competitive markets, thus accelerating their path to sustainability. Financial innovation in SMEs sustainability has been investigated in the literature. Several studies have confirmed that innovative financial services integration reduces redistribution effects and financial execution and allows a higher degree of financial efficiency [22,23].

Existing research indicates that technological adaptability, creative financing, and government involvement are essential for SME growth. However, to the best of our knowledge, no studies have been conducted on Bangladeshi SMEs. With this study, we intend to fill the existing research gap by exploring this study's fresh insight and novelty as follows. First, this study gauges the impact of technological adaptation, innovative finance, and government support for SMEs' survival, especially after the unpleasant shocks 
of the pandemic. Second, we investigated both direct and indirect effects of technological integration and innovative finance on SMEs. Third, we tried to ensure sample heterogeneity for lessening the sample biased in empirical estimation.

This study addresses Bangladeshi SMEs' sustainability by considering the role of technological adaptation, the mode of innovative financial products and services integration, and government support. The study considered a sample of 1395 SMEs representing both manufacturing and services targeted units. The study applied structural equation modelling to detect the effects of innovative finance, technological adaptation, and government role for SMEs' survival. Our study findings document that technical integration, innovative financing, and government role positively support SMEs' survival during the pandemic. Moreover, in terms of indirect effects of innovative finance and technological adaptation, our study reveals a positive statistically significant impact on SME survival through a government role.

The remaining structure of the paper is as follows: Section 2, handling a literature review that focuses on COVID-19 and SMEs; research design and instrumentation explained in Section 3; the survey results and interpretations are inserted in Section 4; discussion and policy implications are displayed in Section 5, and concluding remarks are available in Section 6.

\section{COVID-19, SMEs, and the Bangladesh Economy}

The first COVID-19 case was discovered in Bangladesh on 8 March, and the first fatality occurred on 18 March. COVID-19 has harmed the world economy as well as health and human lives. The global economy is in a severe recession that will likely continue for years. According to the World Bank (2020), most nations will be in recession in 2020 because of COVID-19, and the advanced economies will shrink by $7 \%$. Emerging and developing economies are expected to shrink by $2.5 \%$, the first time in sixty years. As a result, governments worldwide are rushing to implement immediate economic relief measures and long-term economic recovery plans. Considering the experiences of other countries, the Bangladeshi government took urgent steps to shut down the economy to prevent the spread of COVID-19. With all countries reacting simultaneously, a global economic crisis erupted, culminating in an unprecedented economic slump. The global economy has started stabilizing and rising again after the devastating effects of the epidemic; this is a clear sign of fragility and imbalance.

The pandemic's effects have already been perceived in several economic indices from the previous fiscal year regarding the Bangladesh economy. There are expectations of the virus remaining in the environment unless an effective vaccine is developed. As a result, the economic ramifications are likely to persist in the future, albeit the situation is under control. Domestic and foreign demand fell due to the epidemic and subsequent lockdown, and therefore manufacturing units have halted their production. The government initiated the national holiday at the end of March to reduce the spreadsheets. Such a shutdown increased supply restrictions, eventually reducing production levels at an aggregate level. However, export-oriented industries were later permitted to operate on a limited basis. The national holiday was removed at the end of May, with the economy gradually reopened on a conditional basis. The Quantum Index of Industrial Production's (QIIP) general index indicates a significant decline from January to April 2020 and a rebound. However, QIIP in May 2020 was determined to be lower than it was pre-pandemic. The primary drivers of this rapid decline were the manufacturing sector (i.e., garments and knitwear), petroleum products, and other non-metallic mineral products. According to point-to-point estimations, garments and knitwear had growth rates of -84.39 percent and -85.87 percent, respectively, in April 2020.

Conversely, garments and knitwear began rebounding in May 2020, owing to a rise in worldwide demand for RMGs. However, in May 2020, this recovery trend did not hold for petroleum products and cement, which both saw significant deterioration. The public holiday affected construction, and the cement statistics may reflect this. Conversely, the 
pharmaceuticals and medicinal chemicals industry, which includes drugs and pharmaceuticals, expanded favourably.

The Bangladesh government has implemented a significant stimulus scheme in three stages to shield these mass individuals affected by the COVID-19 massive hit by crowding them out of jobs and other activities due to country lockdown [24]. During this pandemic, Bangladesh had two options to manage the imminent economic shock. First, because we do not know how or when to stop this epidemic, a complete lockdown may result in a continuing economic catastrophe. Therefore, economic activities had to be executed for businesses to operate. Second, the government took immediate steps to allocate a lump sum of cash (e.g., BDT 6000 per head for the next 2 months) by using mobile financial services among the masses, mostly those informally working in transport, food, restaurant, salespeople, tourism, farmers, wholesalers, retailers, homemakers, etc.

Furthermore, as a result of industry shutdowns, garment workers and urban day labourers lost their employment. As a result, many individuals with little income relocated from cities to villages, placing the rural economy at risk. In rural regions, egg costs plummeted by 45 percent, milk prices fell by 35 percent, dried fish output fell by 40 percent, and vegetable prices fell substantially. A substantial and immediate response was required to avert the looming social and economic catastrophe in the rural areas. According to the International Monetary Fund, Bangladesh's real GDP growth would slow to 2.0 percent in FY 2019-20, owing to decreasing readymade garment exports, weaker private investment growth, and broader disruptions caused by COVID-19.

\section{Literature Review, Theoretical Development, and Hypothesis Development}

\subsection{Theoretical Development}

Resource-based theory advocated that strategic resources are required to support the firm's market friction and its ability to perceive and capitalize on the opportunity [25]. As suggested by Penrose [26], firms' may be described as a collection of resources because the resources that have long been associated with development at the company level are essential to examine their role in success and survival [27-29]. The optimization of a company's resources is inextricably linked to its success and survival.

Strategic resources are intimately tied to the production possibilities that entrepreneurs recognize and exploit [26]. Resources include the firm's business strategy and client base [30,31], external social capital such as collaborations [32,33], and reputational resources such as trust and brand image [34]. When the economy goes into a crisis, individuals and firms tend to be more cautious about investment decisions. A more significant issue arises when the firm's product or service offerings' value proposition no longer matches the customers' expectations. Firms tried to bridge the trade-off between market proposition and resources availability. Moreover, several firms can detect new market offerings and capitalize on making strategic moves [35]. Suppose a small number of companies seem to be attaining this level of success in the current environment. In that case, the need to continue monitoring, verifying, modifying, and improving the product-market fit to maintain a competitive advantage cannot be overstated.

Physical resources are physical assets that support the firm's activities, such as plants, equipment, and office space [36]. Physical resources (e.g., proprietary equipment and location) are essential to success and development in particular businesses, such as manufacturing or retail firms [37]. Because physical resources are often marketable and fungible [38], they are thus likely to be missed and are the least likely to constitute a stumbling block for high-growth companies. Therefore, the effect on physical resources will pose a substantial danger to developing SMEs during a period of economic slowdown. Growth-oriented SMEs with significant financial resources allow firms to adjust to the changing environment and regain present momentum accordingly [39].

Financial resources refer to the firm's monetary assets, which include equity, debt capital, and retained profits, as well as debt capacity (Barney et al. [40]). Cash flow includes other financial aspects, such as capital, sales, and profit, crucial to business 
success [41]. It may be advantageous to seek equity investment during the crisis, improving its position in different resource component markets [42]. Financial flexibility during pandemics adds certain benefits for SMEs. Cash management is critical for developing SMEs, especially during difficult economic times, because various measures, such as turning to customers and suppliers for more favourable terms or a line of credit, may be relevant and beneficial [43].

Human resources are linked to personnel affiliated with the organization, such as the founder(s), top management team (TMT), board of directors, and workers [44,45]. People are both accumulators and creators of many other assets. Therefore human resources are critical to business development [46,47]. A lack of human resources is often cited as a limitation to company expansion [48].

Organizational resources are characteristics of an organization, namely, the groups of people linked with a company [36]. Planning, regulating, and coordinating systems, reporting structures and operational routines, organizational culture, and human resource management techniques are examples of these resources $[49,50]$. The virtuous development cycle is often centred on the primary development drivers of strategic, human, and financial resources. Growth reversal is often caused by damaged business culture and poor staff morale. Generally, the depletion of organizational resources can aggravate the vicious circle of growth reversal.

\subsection{Literature Survey}

The recent viral outbreak of COVID-19 demonstrates how infectious illnesses spread readily in open markets and can potentially jeopardize a country's economic stability. Previous epidemics such as the Black Death, SARS, Influenza H1N1, and Swine Flu have had comparable economic consequences on a global scale [51]. COVID-19 is more infectious, and the propensity to persist on surfaces complicates its control compared to others. It is considered more infectious than influenza and swine flu due to the ease with which it spreads between individuals. The second characteristic is the delay in discovering and approving treatment medicines because the first infection results in considerable death and economic damage. Another characteristic of COVID-19 is that microorganisms constantly evolve and develop resistance to antibacterial medicines, making them persistent and recurrent danger. The majority of outbreaks repeat, and the present COVID-19 epidemic may develop and reoccur as a second strain of severe acute respiratory syndrome (SARSCoV-2), the first strain of which occurred in 2002-03 (SARS-CoV-1).

Pandemics have both short- and long-term economic and financial effects on economic performance, significantly negative. Economic slow-down reduced revenue collection increased spending, and placed fiscal systems under pressure with inequal income redistribution, especially in developing nations. This type of economic impact was observed in Liberia during the Ebola virus epidemic due to higher public health expenditure, economic loss, and revenue decreases due to the government's inability to collect money, owing to quarantine and curfews. During pandemics, economic shocks are standard due to labour shortages caused by illness, increased mortality, and fear-induced behaviour. Apart from labour shortages, the epidemic's economic downturn is exacerbated by transportation delays, job closures, limitations on trade and travel, and a closed land border.

Small and medium-sized SMEs are well-acknowledged for their crucial role in economic progress, and abundant evidence has been documented in the academic literature. Existing literature suggests that SMEs open new avenues for economic thriving through market creation in international areas and opportunities for domestic resources capitalization $[52,53]$. Therefore, protecting SMEs from unforeseen events and economic shocks is the prime concern for policymakers because the output degradation in SMEs has spillover effects on other segments in the economy [54]. The worldwide viral epidemic has had a significant impact on the employment market. As a result of the recession, all businesses have been hit hard. Maintaining employment, company profitability, and protecting workers and their families in the informal sector is critical. 
SMEs, particularly in developing countries, are in a pitiful condition due to the outbreak of COVID-19 [55]. The consequences of the epidemic on firms are not generally limited to lowering pay, overtime without motivation to be more efficient, delay in emolument or otherwise, etc. Due to COVID-19 and the downswing of existing businesses and firms, many companies in developing and developed countries worldwide have an optimum effect [56,57]. A large number of employees lost their jobs, while others found their pay reduced. For example, high energy costs, bank interest rates, and significant exchange rate volatility resulted from the viral epidemic [16,58].

Literature on pandemic effects on SME shows that Ratnasingam, Khoo, Jegathesan, Wei, Abd Latib, Thanasegaran, Liat, Yi, Othman, and Amir [16] disclosed two critical aspects: financial management and supply chain interruptions, which have considerably affected business operations. Studies furthermore suggest that most SMEs are surrounded by performances, which financially affected their market survival. Unfortunately, the small and medium-sized company is now aware that the poorer and marginalized participants will leave work [59]. In March and April, an online survey was initiated in Beraha and Đuričin [60] to gauge COVID-19 effects on Serbian SMEs from March to April 2020 through collecting responses via an online questionnaire. Study findings documented that Serbia SMEs encountered severe cash flow scarcity and were unable to satisfy liquidity requirements. Furthermore, study results documented that SMEs may have incredible encounters such as market transition, incapacity to pay the fixed liabilities, discharge of workers, and restricted access to capital.

Further evidence was found in the Robinson and Kengatharan [61] study. Study findings revealed that Sri Lankan SMEs are challenged by the shortage of supplies, the downturn in local demand for their goods and services, the challenge of refunding loans and interest, the severe cash shortfall, and the lack of liquidity of savings. The study postulated that the COVID-19 pandemic emotionally challenges all SME staff and operators; thus, government relief and the right strategies and recommendations to help SMEs are vital for moving beyond the crisis. Ojong-Ejoh, Angioha, Agba, Aniah, Salimon, and Akintola [52] documented that employee lay-offs are the critical issue in the initial impact of COVID-19 on SMEs.

Nyanga and Zirima [14] conducted a study to assess SMEs' reactions in Masvingo, Zimbabwe, to COVID-19, applying qualitative techniques, i.e., descriptive tools. Study findings revealed that the lockdown hurt SMEs through suspension of their activities and employment reduction. SMEs demanded assistance from the government through the extended funds to regain business momentum with full swing after economic shocks. Another study was performed by Lu et al. [62] in Sichuan Province, China. Study findings unveiled that unstable market demand, workforce shortage, and liquidity problems had acutely affected the SMEs' incapacity to reopen business operations. Moreover, the study divulged that a liquidity crisis becomes acute in repaying fixed operational expenditures.

Garba [63] executed a study to explore COVID-19 effects on SMEs' performance in Benue state in Nigeria. The study documented adverse effects of the Nigerian economy's pandemic situation, apparent in the SME industry. Findings suggested that COVID-19 is deteriorating SMEs' performance by reducing sales and profitability. The coronavirus pandemic (COVID-19) triggered a global health catastrophe and economic crisis, including halted trade, eliminated jobs, and financial illiquidity, resulting in the recession that deteriorated the performance of SMEs. Lu, Wu, Peng, and Lu [62] evaluated the COVID-19 impact on SMEs in Sichuan Province, China using primary data collected through an online questionnaire from 4807 SMEs. Study findings revealed that SMEs had a severe shortage of raw materials, fewer workers, and minimal market demand, and therefore, SMEs were unable to operate normally. The study also documented that SMEs face difficulties paying their operational charges due to a shortage of revenue generation. Omar et al. [64] investigated the survival strategies adopted by the SMEs to mitigate the impact of the current pandemic by collecting data from 18 March 2020, to 30 April 2020. The study unveiled that the impacts of microcredit organizations on SMEs included organizational challenges 
(e.g., interruption of operations, delivery of the supply chain, forecasting the future course of business, and financial issues). In the meantime, financial and marketing techniques included the main themes of modern survival strategies. The study performed by Akpan et al. [65] investigated the technological adaptation awareness in SMEs during COVID-19 in Malaysia. The study documented that technologically equipped SMEs remain untapped and can mould business operations during the lockdown and operate online.

Adverse effects from the pandemic on macro-and micro-economic aspects are apparent and vary with the economic status' magnitudes. Several macro agents have been experiencing adverse consequences since COVID-19 engrossed the economy, especially the SMEs. Fitriyani et al. [66] postulated that SMEs have bitter experiences during a pandemic due to immense reliance on supply chains that are almost stopped, increases in raw materials price, and readiness to face challenges. Therefore, Hadi [13] suggested that revitalization strategies for SMEs are inevitable because support from different agents will be a prerequisite to reopening business operations. Moreover, many researchers tried to figure out how SMEs can recover from the present pandemic shocks. Khan et al. [67] advocated applying AI-based financing for COVID-infected SMEs as an option with the current financing model in Malaysia. Summary of literature survey display in Table 1.

Table 1. Summary of findings focusing on COVID and SMEs.

\begin{tabular}{|c|c|c|c|}
\hline Authors' & Country & Assessment & Remark \\
\hline $\begin{array}{c}\text { Zimon and } \\
\text { Dankiewicz [68] }\end{array}$ & Poland & Trade strategies & SMEs prefers a conservative approach during economic instability, \\
\hline $\begin{array}{l}\text { Khan, Hassan, } \\
\text { Rabbani and ATIF [67] }\end{array}$ & Bahrain & Islamic finance & $\begin{array}{l}\text { FinTech Islamic financial services play an essential role in saving } \\
\text { COVID affected SMEs }\end{array}$ \\
\hline Islam et al. [69] & Malaysia & Islamic finance & $\begin{array}{l}\text { Access to financial services, digital financial services, and financial } \\
\text { resources exploitation helps SMEs, especially in a pandemic }\end{array}$ \\
\hline $\begin{array}{l}\text { Ojong-Ejoh, Angioha, } \\
\text { Agba, Aniah, Salimon } \\
\text { and Akintola [52] }\end{array}$ & Calabar & Operation & $\begin{array}{l}\text { Pandemic substantially decreases revenue generation capacity by } \\
\text { lowing output sales }\end{array}$ \\
\hline Garba [63] & Nigeria & Performance & $\begin{array}{l}\text { Pandemic has created a difficult time for SMEs for generating } \\
\text { substantial revenue and organizational growth }\end{array}$ \\
\hline $\begin{array}{l}\text { Beraha and } \\
\text { Đuričin [60] }\end{array}$ & Serbia & Performance & $\begin{array}{l}\text { COVID has hampered SMEs' daily business activities, } \\
\text { unemployment creation, delay payment to suppliers, and limited } \\
\text { access to resources. }\end{array}$ \\
\hline Kukanja et al. [70] & Slovenia & $\begin{array}{l}\text { Crisis } \\
\text { management }\end{array}$ & $\begin{array}{c}\text { SMEs mainly concentrate on personnel, cost management, } \\
\text { organizational support, and promotional and customer-related } \\
\text { marketing tactics to recover from pandemic effects }\end{array}$ \\
\hline Islam et al. [71] & Bangladesh & Operation & $\begin{array}{l}\text { IT integration allows SMEs for remote operation during } \\
\text { the pandemic }\end{array}$ \\
\hline Syriopoulos [72] & & Performance & $\begin{array}{l}\text { In turbulent times when opportunities are increasing, convex } \\
\text { policies and strategies work better }\end{array}$ \\
\hline $\begin{array}{l}\text { Omar, Ishak and } \\
\text { Jusoh [64] }\end{array}$ & Malaysia & $\begin{array}{l}\text { survival } \\
\text { strategies }\end{array}$ & $\begin{array}{l}\text { Both financial and marketing survivable strategies have to be } \\
\text { initiated by SMEs for removing these pandemic impacts }\end{array}$ \\
\hline Lu et al. [62] & China & Impact & $\begin{array}{l}\text { Over } 90 \% \text { of small businesses could not return to work due to an } \\
\text { epidemic control shortage, interrupted supply chains, and } \\
\text { diminished market demand }\end{array}$ \\
\hline Chowdhury et al. [73] & Bangladesh & strategies & $\begin{array}{c}\text { Results suggest that short-term implications such as product } \\
\text { expiration, funding shortages, and distributor operations are severe. } \\
\text { In contrast, medium-to-long-term implications promise to be } \\
\text { complicated and ambiguous. } \\
\text { In the long run, many performance criteria, such as return on } \\
\text { investment, GDP contribution, and workforce size, are all predicted } \\
\text { to fall }\end{array}$ \\
\hline
\end{tabular}




\subsection{Hypothesis Development}

\subsubsection{Innovative Finance and SMEs}

Easy access to financial services significantly guided the prospect and growth of SMEs across the world. Thus, financial innovation in SME financing has emerged as critical and discussant facts in different forms. Financial resources, both internal and external, are required for good performance [74]. Due to internal and external constraints, firm performance is primarily determined by variables such as limited resources and strategic decisions [75]. The resource-based perspective advocated that competitive advantage comes from having and using superior resources to those of rivals. Traditional financing for SMEs is in commercial banks, merchant banks, and development banks that provide financial services to SMEs. The financial institution was established to increase the financial balance sheets of the government or private capitalist entities. In order to serve this fundamental business goal, banks often assume many responsibilities for serving the economic agent, such as offering an efficient channel for economic resources reallocation. It is said that businesses need bank loans to launch and manage operations effectively. It is also necessary to coordinate other production variables for investment motives, including the initial demand for capital. There is a clear correlation between bank credit and SME company performance, which is transmitted down to the tier of economic activity in the state.

E-commerce integration in SMEs, such as mobile banking, extensively allows for efficient settlement of financial transactions [76] and establishes business flexibility. In economic consequences, innovative financing mode assists in bringing efficiency in financial transactions and cost reduction. In the study, Muchiri [77] postulated that M-banking adoption in SMEs enables business diversification, cost-effectiveness, security, and accessibility in financial transaction settlements. M-commerce uses wireless networks and computers to conduct monetary value transactions explicitly or implicitly [78]. The number of people who buy products and services using their phones and other mobile devices has increased; further study in mobile banking is needed, as M-Banking is still in its early stages [79]. Banks may provide details and suggest resources to their consumers through online service technology, made possible by smartphone banking [80]. The following hypothesis is to be tested.

\section{Hypothesis 1. Innovative financing support SME survival during the pandemic.}

\subsubsection{Technological Adaptation and SMEs}

Technology is crucial for boosting market competitiveness in the present age of internationalizing corporate operations and globalizing marketplaces [21]. The economies and commercial conditions may change significantly due to globalization, especially in the present economic climate, as corporations persist in attaining economies of scale. The technology revolution also generates unique problems for SME owners in many nations. Technological innovation has a crucial role in enhancing small and medium-sized businesses (SMEs) and long-term growth. It is essential to investigate a country's technical environment to help SMEs achieve sustainable growth [81,82].

Small- and medium-sized enterprises (SMEs) that operate in technologically complex situations may broaden their market by exporting their products internationally. Tiny, mature, or highly competitive local markets may compel them to enter overseas markets, but they may also do so because they sense considerable potential elsewhere [83]. As the globe becomes more linked, trade barriers fall, and transportation and communication grow more efficiently, the internationalization of SMEs is expected to expand ( $\mathrm{Lu}$ and Beamish 2001; McDougall and Oviatt 2000). ICTs have boosted SMEs' competitiveness by improving internal communication and organization, supply chain linkages, and aiding new and improved goods and services [84].

The capacity to reach the target market without a physical presence is an excellent outcome of technology adaptation in SMEs. Technology adaptation enables firms' strength and 
alleviates the condition to reach beyond market territory [85]. Technology adaptation has a strong appeal among SMEs. However, the intensity of integration in the business process is prolonged, especially in developing nations, due to economic structure, social culture, and technological and political state in the economy [86]. Recognizing the enormous potential benefits that technologies can offer organizations, many scholars have paid considerable attention to SMEs' study of technology adoption. Such technology adoption has been investigated within the contexts of both developing and developed nations. Technology adaptation enables firms' technological innovation and significantly improves a firm's performance [87]. The technical environment and notable digitization efforts promote new technologies' progress and adoption, making SMEs competitive and sustainable. Under these conditions, it is critical to reassess the technology environment in emerging nations. The following hypothesis is proposed:

Hypothesis 2. Technology adaptation has a positive association with SMEs' sustainability during the pandemic.

\subsubsection{Government Support and SMEs}

As significant purchasers of products and services, governments provide a significant market potential for all companies, regardless of size. Existing literature on the nexus between government support and SMEs has suggested two lines of motivation that guide governments to support SMEs. First, create positive externalities, suggesting government support for research and development investment [88]. Second, government information to financial institutions and potential investors about SMEs mitigates information asymmetry $[89,90]$.

Governments support SMEs in various ways, including tax breaks, loans, social assistance, and financial assistance [91,92]. Burt [93] proposed that enterprises with vital external networking may readily acquire many resources, particularly beneficial for competitive advantage. At the same time, Barney's [94] resource-based perspective theory claimed that enterprises in a developing economy have a sustained and competitive advantage over competitors with uncommon and unique resources. Furthermore, Sheng et al. [95] indicated that government incentives are critical for developing economies to achieve long-term competitiveness. As a result, government incentives and development initiatives substantially impact a firm's performance [96].

Furthermore, government financial assistance encourages the SME sector to extend its operations internationally, improving SME performance and contributing considerably to economic development [97]. According to Wu et al. [98], SMEs' success in developing countries relies on political and government relationships, and a business can achieve long-term output. Therefore, firms may swiftly create a durable competitive edge in a turmoil market using political solid and government contacts $[99,100]$.

A study was conducted by Loader [101] to evaluate the government's role in SMEs growth in the UK. Study findings disclosed that government support to SMEs facilitates organizational development and structural changes and mitigates internal conflicts, eventually boosting growth prospects. Smallbone and Welter [102] investigated the government's role in SMEs development in a transition economy. The study documented that a congenial business environment and robust regulatory framework support SMEs' progress to sustainability. Furthermore, the government's role is critical in effective policy formulation and efficient implementation, ensuring equitable opportunities for SMEs in competitive market advantages. Government efforts aim to provide the institutional and systemic circumstances necessary to foster firm-level capability enhancement, diversification, and new businesses [103]. Absorptive ability is a critical strategic resource for SMEs since it enables them to achieve a competitive edge and sustained development [104].

Arshad et al. [105] investigated the government role in SMEs' absorptive capacity in Pakistan. Study findings unveiled that government business support services are positively associated with SMEs' capacity to handle unanticipated circumstances. 
During the pandemic, assistance from the government emerged as penance for SMEs survival. Nonetheless, government support will be immensely appreciated in due course for SME development across the world. A generous helping hand from the government helps a company become more environmentally conscious; it may be an opportunity to inform the organization on sustainable practices, help transform attitudes toward sustainability and have a more persistent connection with the natural environment [106]. In the context of government support during the pandemic, the literature suggests that SMEs achieve innovation, technology adaptation, and technical know-how [107]. SMEs felt confident about their revival from the pandemic when they experienced the presence of the government in the recovery process with financial and policy assistance [108]. The effects of government support for SMEs survival are to be tested with the following hypothesis:

Hypothesis 3. Government support is critically essential during the pandemic for SMEs revival.

Hypothesis 4. Government support mediates the role between innovative finance and sustainability.

Hypothesis 5. Government support mediates the role of technological adaptation and sustainability.

The hypothesized relationship and conceptual framework display in Figure 1.

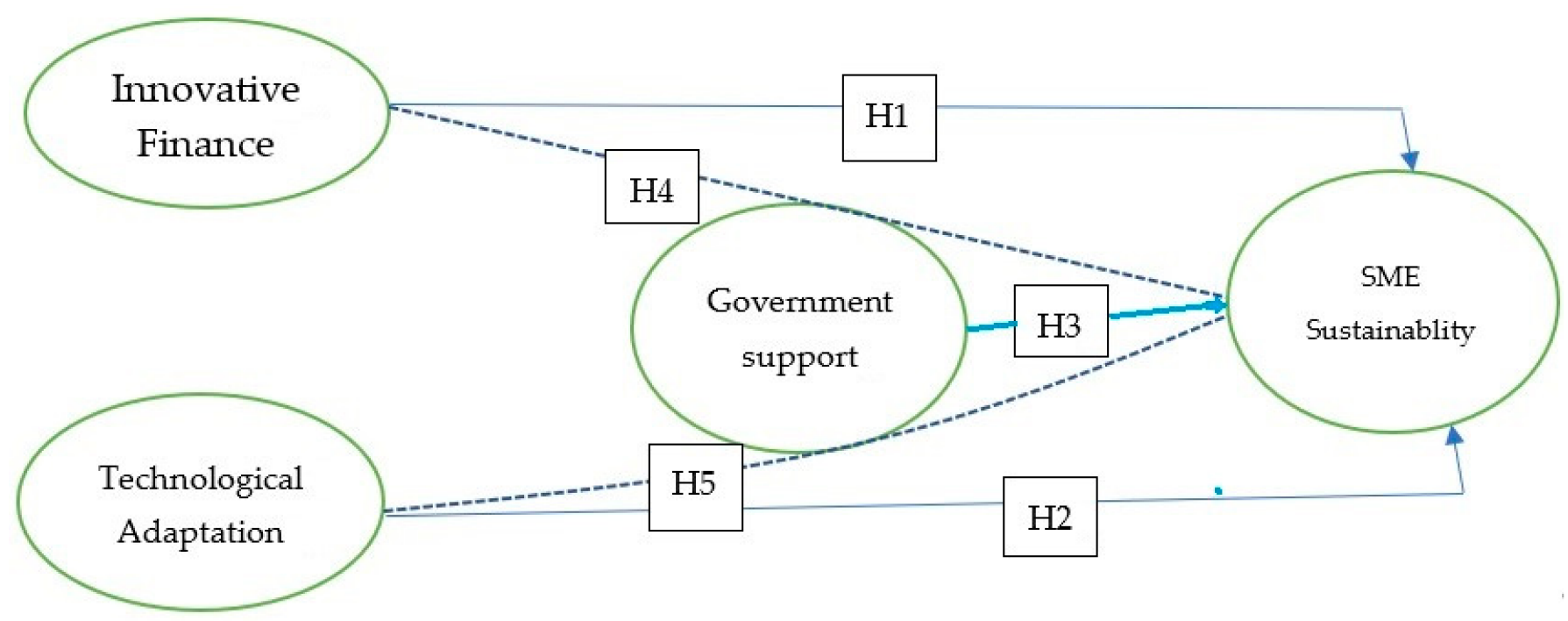

Figure 1. The conceptual model with the proposed hypothesis for the study.

\section{Research Sample and Instruments}

\subsection{Research Design and Sample}

The study population comprised about 7.8 million SMEs in Bangladesh, further subgrouped into 132 units per their operation (Bangladesh Bank 2021). However, the study only concentrated on SMEs located in Dhaka city because it is relatively easy to connect with them through their corresponding electronic channel. Prior consent was initiated before we sent the questionnaire link for their responses. Their initial acknowledgement was considered in determining the sample frame of the study. Altogether, 5780 SMEs were targeted and sent emails for their acknowledgement about the study survey, and after 30 days, lead time from the day of initial execution, we acquired pre-acceptance from 2041.

Following the existing literature, a structured questionnaire was constructed following the research variables regarding SMEs' sustainability [21,109], technological adaptation, innovative finance, and government support. A structured questionnaire allows the receiving of respondents' opinions, attitudes, values and beliefs of the sample [110]. Data were collected for the period from 10 December 2020, to 28 January 2021. A sample of 2000 SMEs was considered, and an online structured questionnaire was sent for their 
response (see Table 2). Altogether, 1895 responses were returned after the final careful data sorting study found a total of 1395 respondents were dully filled (as a \% of 69.75) and could be utilized for further assessment.

Table 2. Technical details of the research.

\begin{tabular}{cc}
\hline Category & Remarks \\
\hline Sector & SMEs \\
Geographical location & Bangladesh (Dhaka) \\
Methodology & Structured questionnaire \\
Procedure & Random sampling \\
Sample size (response) & 2000 (1395) \\
Period of data collection & From 10 December 2020, to 28 January 2021 \\
\hline
\end{tabular}

\subsection{Measurement Models}

The study considered two independent variables: financial innovation and technological adaptation, one dependent variable known as SMEs' sustainability, and a mediating variable: government support. The measurement model for the study is displayed in Table 3.

Table 3. Measurement of variables.

\begin{tabular}{|c|c|c|c|c|}
\hline Variable Name & Definition & Items & Reference & Likert Scale \\
\hline SMEs' sustainability & $\begin{array}{l}\text { Improve response to the customer; } \\
\text { improve market intelligence; } \\
\text { enhance the relationship with the } \\
\text { trading partner }\end{array}$ & 4 & $\begin{array}{l}\text { Das, Kundu and Bhattacharya [21], } \\
\text { Prasanna, Jayasundara, Naradda } \\
\text { Gamage, Ekanayake, Rajapakshe } \\
\text { and Abeyrathne [109] }\end{array}$ & $\begin{array}{l}\text { Disagree } 1 \text { to } \\
\text { strongly agree } 5\end{array}$ \\
\hline $\begin{array}{l}\text { Technological } \\
\text { adaptation }\end{array}$ & $\begin{array}{l}\text { IT adoption is suggested for small } \\
\text { businesses to reduce operating } \\
\text { costs, improve service to } \\
\text { consumers, increase reaction time } \\
\text { between producer and customer, } \\
\text { producer and input supplier, } \\
\text { improve market knowledge, and } \\
\text { strengthen trade relationships }\end{array}$ & 5 & $\begin{array}{l}\text { Meng, Qamruzzaman and } \\
\text { Adow [111] }\end{array}$ & $\begin{array}{l}\text { Disagree } 1 \text { to } \\
\text { strongly agree } 5\end{array}$ \\
\hline Financial innovation & $\begin{array}{l}\text { Financial products and services for } \\
\text { operational efficiency }\end{array}$ & 5 & $\begin{array}{l}\text { Ye and Kulathunga [112]; Ardic, } \\
\text { Mylenko and Saltane [113]; Okello } \\
\text { Candiya Bongomin, Mpeera Ntayi, } \\
\text { Munene and Akol Malinga [114] }\end{array}$ & $\begin{array}{l}\text { Disagree } 1 \text { to } \\
\text { strongly agree } 5\end{array}$ \\
\hline Government support & $\begin{array}{l}\text { The tax holiday, subsidized rate } \\
\text { financing, financial incentives }\end{array}$ & 5 & $\begin{array}{l}\text { Alkahtani et al. [115]; Zamberi } \\
\text { Ahmad and Xavier [116] }\end{array}$ & $\begin{array}{l}\text { Disagree } 1 \text { to } \\
\text { strongly agree } 5\end{array}$ \\
\hline
\end{tabular}

\subsection{SMEs Sustainability}

Difficulties in accessing SMEs' pertinent information to squeeze the scope measures the issue of SMEs' sustainability. The owners of SMEs have shown reluctance to disclose the firms' performance information needed to evaluate performance sustainability, and further reexamining the accuracy and authenticity is impossible due to the lack of an official database. Nonetheless, several researchers have tried to investigate the incorporation of scale items in measuring SMEs' sustainability (see Das, Kundu and Bhattacharya [21] and Prasanna, Jayasundara, Naradda Gamage, Ekanayake, Rajapakshe and Abeyrathne $[109,117])$. The study extracted and modified the items for SME's sustainability. All responses were given a five-point Likert scale ranging from extremely poor (1) to extremely good (5). 


\subsection{Innovative Finance}

Application and integration of financial products and services for executing business transactions play a critical role in ensuring efficient management of a firm. The idea of innovative finance or financial innovation is one of the widely interchangeable words that has been considerably used for explaining the availability of financial services for SMEs [118]. Over the past decades, both developed and developing nations have embraced the idea of financial services diversification, including mobile banking, internet banking, agent banking, and ATM services through the channel of financial institutions to ensure efficient financial intermediation and efficiency in the financial system [119]. The offerings of financial diversifications allow business enterprises, regardless of their size, to capitalize on the underlying benefits and optimize the resources constraints, especially SMEs, to manage the settlement of their financial transactions. SMEs' access to financial services has augmented through the diffusion of innovation, and their positive role was also detected, especially during the pandemic. It is implied that the online payment gateway opens a new avenue for them to receive money from customers and payments to suppliers without any physical contact with each other. In a study, Engwa et al. [120] advocated that online banking facilities for SMEs are a factor for thriving business by allowing efficient financial intermediation and due date settlement. Measuring innovative finance has no direct measurements available in the existing literature; however, the impact of financial services accessibility on SMEs has been investigated. Following the study of Okello Candiya Bongomin et al. [114], Ardic et al. [113], and Ye and Kulathunga [112], the study considered the items and modified SMEs' direction for receiving responses regarding the attitudes of SMEs toward innovative finance. A five-point Likert scale was assigned from 1 for strongly disagree to 5 for strongly agreed.

\subsection{Technological Adaptation}

A firm's technological integration allows competitive market privilege over others, and the propensity to accept advanced technology in operations is significantly guided by owners and managers perceptions [111]. In SMEs, technological adaptation creates an avenue to expand current market opportunities and offers capacity maximization with optimal economic resources. Following existing literature, see for instance Muneeb et al. [121], Meng, Qamruzzaman and Adow [111], and CHIGOZIE et al. [122], the study considered and modified the item and prepared it as the latent construct for measuring the state of technological adaptation in the firms. Five points Likert scale was considered, ranging from strongly disagree (1) to strongly agree (5).

\subsection{Government Support}

A firm's establishment, growth and sustainability do not rely on entrepreneurs' creativity. Instead, the business ambience plays the deterministic role: the government actions and coordination enable firms to thrive with limited resources [102]. The government can assist versatilely in SMEs' progress, including external financing support, training and development, technological assistance, and tax incentives. Aggregate market competitiveness and pleasant business ambience have a progressive effect on SMEs' sustainability and can be ensured by the government by offering an efficient regulatory framework and practical implementation [105]. Following existing literature focusing on government support and SMEs (see $[101,105,123,124])$, the study developed and modified five latent constructs for measuring the SMEs' perception regarding the role of government support in sustainability. A five-point Likert scale was assigned from strongly agree (5) to disagree strongly (1).

\subsection{Descriptive Statistics}

A demographic profile of simple SMEs is displayed in Table 4. Referring to SMEs' business composition, it is apparent that $53.76 \%$ of SMEs belong to manufacturing businesses such as handicrafts units, fashion houses, and boutique shops in most cases, and $46.24 \%$ belong to services-focused units such as beauty parlours, fast food shops, and book shops. 
According to SMEs' establishment, the majority of the sample SMEs conducting business over the period $10-15$ years (39.71\%), 17.56\% SMEs were in operation less than $10 \%$, and $23.15 \%$ SMEs were conducting business for the period $15-20$ years and $19.57 \%$ SMEs were conducting business over 20 years. In terms of employment perspective, $49.10 \%$ of SMEs disclosed their level of employee engagement to be between $25-150$, and $38.35 \%$ of SMEs had less than 25 employees in their operation. For SMEs classification based on earning capacity, $41.58 \%$ of SMEs revealed annual revenue generation between 5-10 million (BDT). The diversification of sample composition allowed versatility in responses and allows for generalized assessment.

Table 4. Demographic profile of SMEs.

\begin{tabular}{|c|c|c|c|c|}
\hline Classification & & Total & $\%$ & 1395 \\
\hline \multirow[t]{2}{*}{ Gender } & Male & 915 & $65.60 \%$ & \\
\hline & Female & 485 & $34.40 \%$ & \\
\hline \multirow[t]{2}{*}{ Nature of business } & Manufacturing Units & 750 & $53.76 \%$ & \\
\hline & Services units & 645 & $46.24 \%$ & \\
\hline \multirow[t]{4}{*}{ Yeas of establishment } & less than 10 & 245 & $17.56 \%$ & 1395 \\
\hline & between 10 to 15 years & 554 & $39.71 \%$ & \\
\hline & between 15 to 20 years & 323 & $23.15 \%$ & \\
\hline & more than 20 years & 273 & $19.57 \%$ & \\
\hline \multirow[t]{3}{*}{ No of employees } & more than 150 & 175 & $12.54 \%$ & 1395 \\
\hline & between 25 to 150 & 685 & $49.10 \%$ & \\
\hline & less than 25 & 535 & $38.35 \%$ & \\
\hline \multirow[t]{3}{*}{ Average revenue } & more than 10 million & 375 & $26.88 \%$ & 1395 \\
\hline & between 5 to 10 million & 580 & $41.58 \%$ & \\
\hline & less than 5 million & 440 & $31.54 \%$ & \\
\hline
\end{tabular}

\subsection{Methodology for Hypothesis Testing}

SPSS (26.0) and AMOS (26.0) software were utilized for the analysis of data. The study considered structural equation modelling (SEM, hereafter) and seemed appropriate for handling the model's causal effects with latent construct and mediating variables [125]. Moreover, SEM can provide precise and relevant results because of its resilience and efficiency [126]. SEM is advantageous to other methods since it enables researchers to generate several indicator variables for each construct without split analysis, resulting in invalid and understandable conclusions [127]. SEM takes measurement error into account by calculating the measurement error sections of the variables under examination [128]. Consequently, the connection between variables is both dependable and neutral [129]. Additionally, SEM can inspect complex connections and hypotheses in real-time, including mean structures and group estimates that are difficult to perform with other prototypes and methods [130].

SEM has an intriguing property in that it offers a significance test for the appropriateness of each judgmentally determined parameter value as well as an estimate of the anticipated change in the parameter as if it were freely estimated [131]. This enables researchers to determine the degree to which their evaluation matches the data. In the spirit of the decision calculus method, this information may result in updated judgmental estimates, model re-estimation, and a new evaluation of the appropriateness of judgmental estimates [132].

\subsection{Instrument Validation}

Results of initial research instruments validation are displayed in Table 5. The test statistics of the skewness test range are between -1 to +1 , suggesting the data of sustainability, technological adaptation, innovative finance, and government support are typically distributed [133]. The study documents that the factor loading statistics of each latent construct are more significant than 0.7 , which is desirable for further model implementation. Reliability and validity values are purely based on the extreme loading values [134]. 
Furthermore, regarding the variance inflation factor (VIF), it is apparent that test statistics of each variable are within the accepted line, i.e., $<3.00$, confirming the absence of multicollinearity in the data set.

Table 5. Outer loading and multicollinearity.

\begin{tabular}{|c|c|c|c|c|c|}
\hline & [1] & [2] & [3] & [4] & VIF \\
\hline IF1 & 0.912 & & & & 2.8593 \\
\hline IF2 & 0.895 & & & & 2.0832 \\
\hline IF3 & 0.914 & & & & 2.7827 \\
\hline IF4 & 0.884 & & & & 1.5543 \\
\hline IF5 & 0.812 & & & & 1.3554 \\
\hline TA1 & & 0.984 & & & 2.1634 \\
\hline TA2 & & 0.887 & & & 2.8694 \\
\hline TA3 & & 0.904 & & & 2.7493 \\
\hline TA4 & & 0.886 & & & 1.2811 \\
\hline GS1 & & & 0.913 & & 1.5771 \\
\hline GS2 & & & 0.889 & & 2.8375 \\
\hline GS3 & & & 0.911 & & 1.8847 \\
\hline GS4 & & & 0.886 & & 1.823 \\
\hline GS5 & & & 0.987 & & 1.0284 \\
\hline SME1 & & & & 0.885 & 2.8593 \\
\hline SME2 & & & & 0.875 & 2.0832 \\
\hline SME3 & & & & 0.941 & 2.7827 \\
\hline SME4 & & & & 0.911 & 1.5543 \\
\hline SME5 & & & & 0.875 & 1.3554 \\
\hline
\end{tabular}

Note: FI, financial innovation; TA, technological adaptation; GS, government support; SME, small and medium enterprises.

Referring to factor loading latent constructs of each measurement variable, the study documents that five (05) constructs for measuring innovative finance are efficient in extracting opinions regarding innovative finance's role in sustainability since the coefficient of each item is higher than the cut-off value. The four items measuring technological adaptation in the model confirm suitability in further assessment with the factor loading greater than 0.70 . The factor loading test statistics of government support are between 0.886 to 0.987 , suggesting the efficiency in capturing the opinion about government support of sustainability. Finally, the measurement items for sustainability and test statistics of factor loading were established regarding internal efficiency since the test statistics are higher than cut-off values. According to factors loading test statistics for all four measurement variables, the data set is efficient and internally sound for further assessment.

Table 6 displays the test statistics for evaluating the reliability and the convergent validity of the constructs. For ideal research constrict, Sarstedt et al. [135] determined the test statistics of Cronbach's alpha, rho_A, and CR threshold should be $>0.70$, and the value of the average variance extracted (AVE) should be $>0.50$. Study findings disclosed that the test statistics of all target benchmarks are higher than the standard line, implying no reliability and validity issue of the constructs.

Table 6. Reliability of constructs.

\begin{tabular}{ccccc}
\hline & Cronbach's Alpha & rho_A & CR & AVE \\
\hline Innovative finance & 0.924 & 0.916 & 0.907 & 0.793 \\
IT adaptation & 0.897 & 0.914 & 0.874 & 0.795 \\
Government support & 0.918 & 0.926 & 0.892 & 0.803 \\
SMEs' sustainability & 0.922 & 0.924 & 0.897 & 0.816 \\
\hline
\end{tabular}

The results of discriminant validity for the study are displayed in Table 7 with two available criteria such as Fornell and Larcker criteria [136] and Heterotrait-Monotrait ratio 
of correlation [137], by following empirical studies such as Yusoff et al. [138], Ab Hamid et al. [139] \& Voorhees et al. [140]. The diagonal values of Fornell and Larcker should be greater than the remaining values. The remaining values of the Fornell and Larcker ratio were the correlation between the constructs. Contrarily, the value of HTMT should be $<0.85$, which indicates no discriminant validity issue. The study found that there was no discriminant validity issue.

Table 7. Discriminant validity.

\begin{tabular}{cccccccccc}
\hline \multirow{2}{*}{ Constructs } & \multicolumn{4}{c}{ Fornell and Larcker } & \multicolumn{5}{c}{ Heterotrait-Monotrait } \\
\cline { 2 - 10 } & AF & ES & LC & PWEA & SL & AF & ES & LC & PWEA \\
\hline IF & 0.890 & & & & & - & & & \\
TA & 0.652 & 0.891 & & & & 0.591 & - & & \\
GS & 0.702 & 0.668 & 0.995 & & & 0.773 & 0.761 & - & \\
SME & 0.691 & 0.721 & 0.618 & 0.903 & & 0.713 & 0.701 & 0.61 & - \\
\hline
\end{tabular}

The study performed measurement models with all latent constructs; results are reported in Table 8 . Considering the measurement model goodness fit index's test statistics, conclusive evidence establishes and suggests the model's internal consistency. For the absolute fit model, we observed that the goodness fit index (GIF) value is 0.995. The adjusted goodness of fit index (AGIF) is 0.978 , greater than the model fit index. Conversely, the root means square error of approximation (RMSE) and standardized root mean square residual (SRMR) value is 0.03 and 0.028 , respectively, lower than the ideal model fit cut-off value. For incremental fit measures, the study revealed that the Tucker-Lewis index value (TLI) is 0.922. Comparative fit index (CFI) is 0.938. The normed fit index (NFI) is 0.895, and the incremental fit index (IFI) is 0.917 , respectively, close to 1 . Therefore, one can conclude that the incremental model fit estimation also confirms an ideal model for further analysis. For a parsimonious model fit index, we found the ratio between chi-square and degrees of freedom ratio $\left(\chi^{2} / \mathrm{df}\right)$ is 1.75 . According to Arbuckle [141], the ratio should be in a range from 1 to 3 . Moreover, the value of parsimony adjustment to the NFI (PNFI) and parsimony adjustment to the CFI (PCFI) is also higher than the standard level. Hence, one can conclude that construct validity was achieved in this study since at least one fit index from each category meets the requirements for adequate evidence of model fit.

The study implements the structural model for detecting the possible causal effects of technology adaptation and innovative finance toward SME sustainability through the mediating effects of government support during the pandemic. The results of line coefficients in terms of direct and indirect effects on SMEs survival are displayed in Table 9, panel-A for direct effects and Panel-B for indirect effects, respectively.

For direct effects, study findings document positive, statistically significant effects running from technological adaptation to SMEs' survival (a coefficient of 0171), innovative finance to SMEs' survival (a coefficient of 0.272), and government support to SMEs' survival (a coefficient of 0.207 ), which is desirable. The study suggests that SME units are high. IT integrated into operations and considered an innovative financing model for receipts and payment in the financial transaction has a higher intensity for reviving from presentstate, unbearable situations. Besides, government support during pandemics exposes a positive, statistically significant role for SMEs' survival. It indicates that assistance from the government allows firms to feel confident about regulatory assistance, thus acting as a potential motivating factor for recovery from the disadvantageous scratch of the pandemic. However, the impact of technology adaptation and innovative finance on government support reveals positive but statistical insignificance. 
Table 8. Measurement model results.

\begin{tabular}{|c|c|c|c|c|c|}
\hline & $\mathbf{Y}$ & $\mathbf{R}^{2}$ & CR & AVE & The Goodness of Fit Index \\
\hline IF1 & 0.855 & 0.731 & \multirow{5}{*}{0.934} & \multirow{5}{*}{0.782} & \multirow{19}{*}{$\begin{array}{c}X_{62}^{2}=11,036(p=0.00) \\
\text { NFI }=0.917 \\
\text { RFI }=0.895 \\
\text { GFI }=0.995 \\
\text { IFI }=0.938 \\
\text { CFI }=0.938 \\
\text { TLI }=0.922 \\
\text { RMSEA }=0.03\end{array}$} \\
\hline IF2 & 0.867 & 0.752 & & & \\
\hline IF3 & 0.87 & 0.757 & & & \\
\hline IF4 & 0.943 & 0.889 & & & \\
\hline IF5 & 0.86 & 0.740 & & & \\
\hline TA1 & 0.888 & 0.789 & \multirow{4}{*}{0.932} & \multirow{4}{*}{0.777} & \\
\hline TA2 & 0.829 & 0.687 & & & \\
\hline TA3 & 0.945 & 0.893 & & & \\
\hline TA4 & 0.869 & 0.755 & & & \\
\hline GS1 & 0.84 & 0.706 & \multirow{5}{*}{0.925} & \multirow{5}{*}{0.757} & \\
\hline GS2 & 0.834 & 0.696 & & & \\
\hline GS3 & 0.935 & 0.874 & & & \\
\hline GS4 & 0.945 & 0.893 & & & \\
\hline GS5 & 0.837 & 0.701 & & & \\
\hline SME1 & 0.921 & 0.848 & \multirow{5}{*}{0.965} & \multirow{5}{*}{0.876} & \\
\hline SME2 & 0.906 & 0.821 & & & \\
\hline SME3 & 0.952 & 0.906 & & & \\
\hline SME4 & 0.964 & 0.929 & & & \\
\hline SME5 & 0.921 & 0.848 & & & \\
\hline
\end{tabular}

Table 9. Hypothesis testing with the structural model.

\begin{tabular}{|c|c|c|c|c|c|}
\hline Relationships & Path & Std. Dev. & $t$ Value & $p$-Value & Domark \\
\hline \multicolumn{6}{|c|}{ Panel-A: Direct effects } \\
\hline $\begin{array}{c}\text { Technology adaptation positively induces SME } \\
\text { sustainability during pandemic }\end{array}$ & 0.171 & 0.065 & 4.538 & 0.003 & $S$ \\
\hline $\begin{array}{l}\text { Innovative finance positively induces SME } \\
\text { sustainability during the pandemic }\end{array}$ & 0.272 & 0.064 & 6.609 & 0.000 & $S$ \\
\hline $\begin{array}{l}\text { Government role positively induces SME } \\
\text { sustainability during the pandemic }\end{array}$ & 0.207 & 0.072 & 5.416 & 0.023 & $S$ \\
\hline $\begin{array}{l}\text { Technology adaptation positively induces } \\
\text { government support during pandemic }\end{array}$ & 0.192 & 0.074 & 2.594 & 0.23 & \\
\hline $\begin{array}{l}\text { Innovative finance positively induces } \\
\text { government support during a pandemic }\end{array}$ & 0.186 & 0.069 & 2.695 & 0.113 & \\
\hline \multicolumn{6}{|c|}{ Panel-B: Indirect effects } \\
\hline $\begin{array}{c}\text { Government role has positive mediating } \\
\text { effects between technological adaptation and } \\
\text { SME sustainability }\end{array}$ & 0.079 & 0.077 & 3.3506 & 0.001 & support \\
\hline $\begin{array}{l}\text { Government role has positive mediating } \\
\text { effects between innovative finance and } \\
\text { SMEs sustainability }\end{array}$ & 0.129 & 0.067 & 2.5074 & 0.006 & support \\
\hline
\end{tabular}

Panel-B in Table 9 reports the mediating effects of government role's indirect effects of technological adaptation and innovative finance on SMEs' survival. The study documents the positive, statistically significant links to SME's survival, i.e., TA $\rightarrow \mathrm{GS} \rightarrow \mathrm{SME}$ 
(a coefficient of 0.079 ) and IF $\rightarrow$ GS $\rightarrow$ SME (a coefficient of 0.129 ). These findings suggest that government support is critical for surviving small enterprises, especially in the pandemic state.

The study also performs several models fit analyses to confirm the best fit for analysis. Table 10 reports full information on the goodness of model fit index in three groups. For absolute fit, our study detected that the goodness of fit index (0.964) and adjusted good-offit index (0.949) is higher than the standard-fit index. We also observed that the index of RMSE (0.011) and SRMR (0.025) is less than 0.05, confirming the best fit for analysis. For the relative fit index, the fit index Tucker-Lewis index (TLI) value is 0.998. Comparative fit index (CFI) is 0.998. Normed fit index (NFI) is 0.956, and incremental fit index (IFI) is 0.998. All the fit indices are higher than the standard model fit widely accepted $(>0.90)$. For the parsimony fit index, the entire model fit index satisfied the standard criteria.

Table 10. Model fit index for a structural model.

\begin{tabular}{|c|c|c|c|c|}
\hline Category & Name of Index & Values & Fit Value & Inference \\
\hline & The goodness of fit index (GIF) & 0.964 & Close to 1 & Fit \\
\hline Absolute & Root mean square error of approximation(RMSE) & 0.011 & $<0.05$ & Fit \\
\hline fit & Standardized root mean square residual (SRMR) & 0.025 & $<0.08$ & Fit \\
\hline \multirow[t]{2}{*}{ measures } & Adjusted good-of-fit index (AGFI) & 0.949 & $>0.90$ & Fit \\
\hline & Tucker-Lewis index (TLI) & 0.998 & $>0.90$ & Fit \\
\hline Incremental & Comparative fit index (CFI) & 0.998 & $>0.90$ & Fit \\
\hline fit & Normed fit index (NFI) & 0.956 & $>0.90$ & Fit \\
\hline \multirow[t]{3}{*}{ measures } & incremental fit index (IFI) & 0.998 & $>0.90$ & Fit \\
\hline & Chi-square test $\left(\chi^{2}\right)$ & 227.87 & $p>0.05$ & \\
\hline & Degrees of freedom (Df) & 129 & $\geq 0$ & \\
\hline Parsimonious & Chi-square/degrees of freedom ratio $\left(\chi^{2} / \mathrm{df}\right)$ & 1.76 & $1-5$ & Fit \\
\hline fit & Parsimony Adjustment to The NFI (PNFI) & 0.758 & $>0.50$ & Fit \\
\hline measures & Parsimony Adjustment to The CFI (PCFI) & 0.792 & $>0.50$ & Fit \\
\hline
\end{tabular}

\section{Discussion and Theoretical Contribution}

\subsection{Discussion}

During COVID-19, the survival of business units had become the prime issue across the world, especially SMEs' sustainability. The adverse impact of the global pandemic has been scratching in every corner of the economy by disrupting the business process, shifting consumption patterns, input supplies congestion, and market demand approach to zero. SMEs located in Bangladesh are not out of such a nightmare. However, the government initiatives, including financing supports, institutional cooperation, and owners' keen understanding, have helped to assist firms in reviving and continuing the business transaction with information technology adaptation.

Hypothesis 6. Technology adaptation assists in SMEs survival.

Both developed and developing countries recognize the increasing importance of small- and medium-sized enterprise (SME) involvement in implementing technology. Proven concepts and philosophies have been widely employed in the implementation of western technologies. The implementation of these ideas into developed countries has not been extended thus far. The application of technology to the private sector is critical for business growth [142]. Regarding the impact of technology adaptation on SMEs, survivals reveal a positive, statistically significant association. Technology adaptation in SMEs allows business diversification and innovativeness in operation, thus opening an avenue for operating firms without physical existence based on online platforms. Integration of digitization and restructuring of business operations enhances the firm's possibility of surviving during unaware situations [69]. SMEs' technology inclusion in operation has higher possibilities for surviving under an unrespectable economic state due to cost reduction 
and workforce layoff. Customers' commitment can be the possible alternative strategy that is pettily connected with technology adaptation. In a study, Islam, Igwe, Rahman, and Saif [71] postulated that IT integration and support can boost SMEs' regrowth during and post-pandemic. Because of working with the online platform, SMEs can maintain the connection with customers only in services. Akpan, Udoh, and Adebisi [65] advocated that technically exposed and well-equipped SMEs have experienced less volatility in their operation during the state of unexpected incidence. Furthermore, SMEs' business operation based on technology has, to some extent, remain untapped during COVID-19 lockdown due to flexible operational capacity and adjustable with the economic state.

Technology-based businesses create more jobs and generate income but have smaller employment losses and a better perspective for wealth production by new company advancement and growth than non-technology companies [87]. Developing new inventions also occurs in R\&D organizations. Since emerging innovations are constantly becoming more relevant to the marketplace, all rising organizations follow this incubation policy.

Hypothesis 7. Innovative finance assists SMEs survival in the pandemic.

Referring to study findings with structural modelling, it is apparent that positive, statistically significant effects running from innovative finance in SME operation play an important role in surviving the pandemic. This finding suggests that integration and application of internment banking and mobile banking help SMEs pay and collect the receipt from customers during pandemics, which allows the settling of their transactions with negligible virus contamination, which is a big challenge with physical banking transactions.

The owners' attitudes regarding online and mobile banking in business and their role in the pandemic. Study documents (see, Figure 2): Most SME owners felt that innovative financing models to settle financial transactions are suitable investments because online platform transactions allow greater flexibility and no physical appearance. Furthermore, financial transaction settlement was a drawback during the pandemic due to the shutdown of financial institutions and liquidated cash shortage.

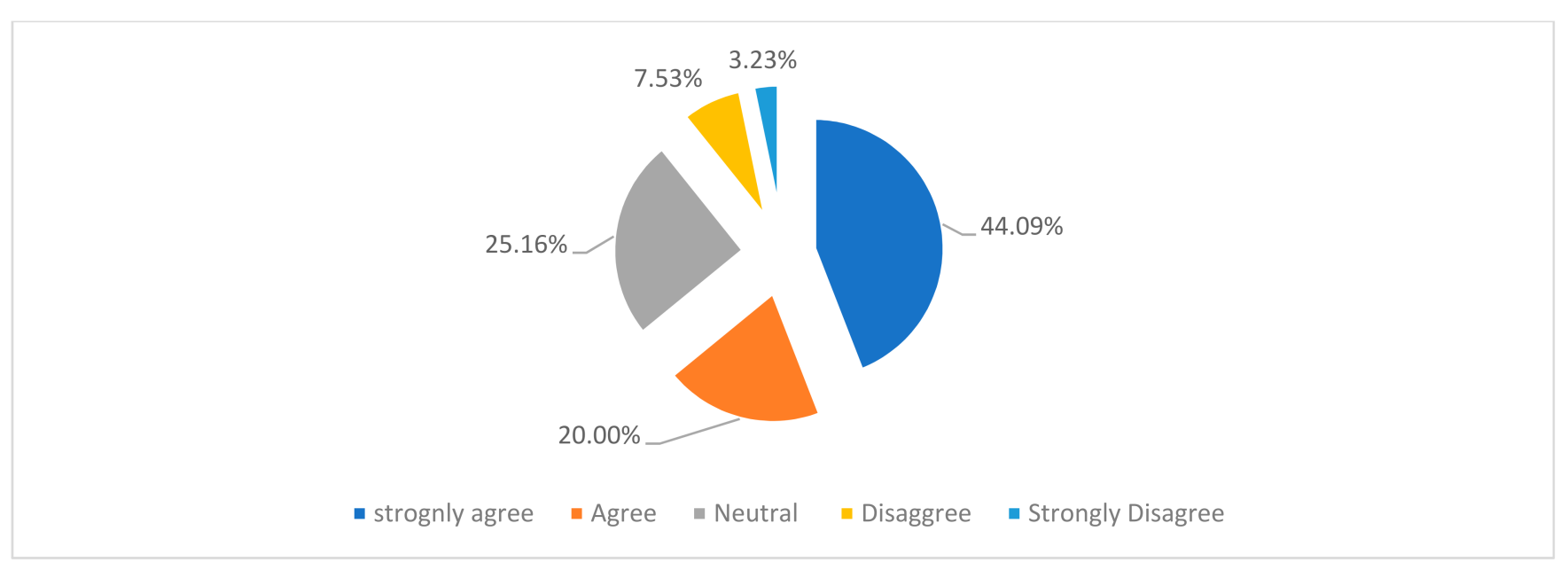

Figure 2. SMEs attitudes toward innovative modes for financial settlement during COVID-19.

Hypothesis 8. Government support is critically essential during the pandemic for SMEs revival.

It is postulated that the government's role is critical during a pandemic for SMEs' survival. Referring to the causal model coefficient, the study documents that initiatives and supports, including financial incentives, credit payment extension, no classification, and regulatory assistance, positively impact SMEs' revival during the present state of the economy. According to Islam, Igwe, Rahman, and Saif [71], financial constraints become 
the decisive facts for recovery from any pandemic, especially the global pandemic when all the scopes of an operation become halted, and unforeseen uncertainty is approaching.

According to the survey outcome (see Figure 3), about $49.18 \%$ of owners of SMEs argued that during the pandemic, the government's decision to issue credit extension for SMEs in the form of nonpayment of loan instalment to financial institutions was the best alternatives. Moreover, $22.22 \%$ of SME owners felt that the government's financial package assists them immensely when they are in severe liquidity shortage and cannot pay their day-to-day operational expenditures.

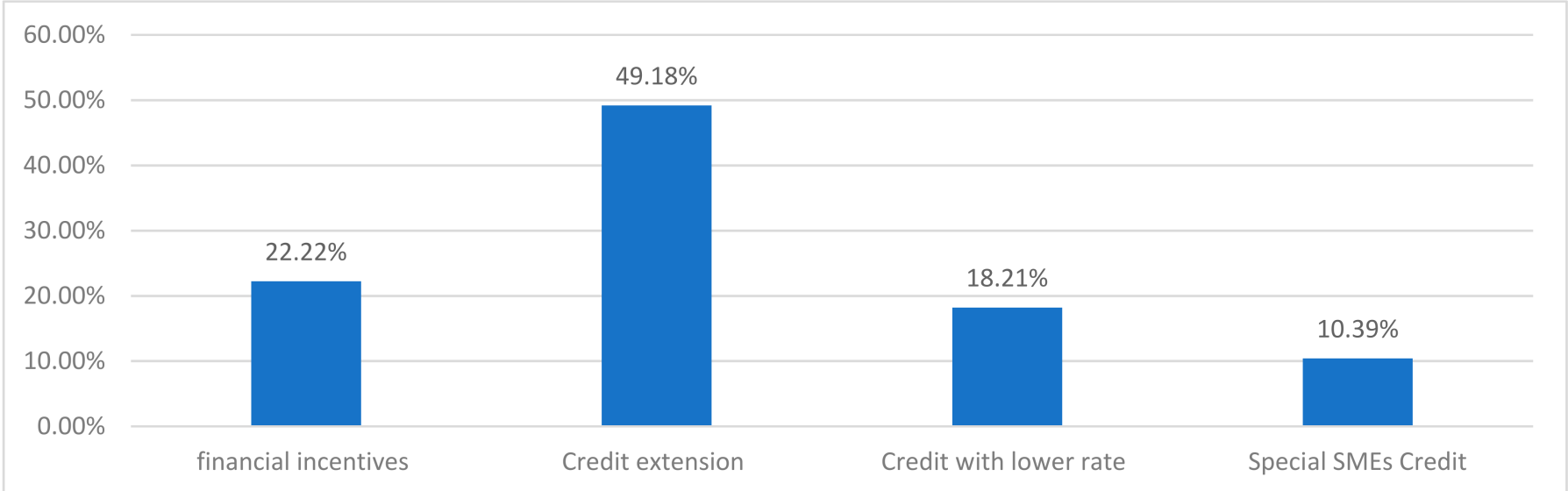

Figure 3. Owners' perception about government support.

\subsection{Theoretical Contribution}

According to business theory [143], all organizations must consider three types of assumptions affecting their work: the organizational environment, mission accomplishment, and the competencies and resources that enable mission fulfilment. However, the hypothesis must be reconsidered in the future, particularly if the company has experienced considerable success or failure. The COVID-19 epidemic has shown significant shortcomings in many SMEs' current business strategies and processes. When the business environment becomes chaotic, the business theory allows firms to reassess their three fundamental assumptions. Since SMEs have been impacted financially because of their low resources and skills, a new strategy must be devised to improve their ability to confront the epidemic. As a result of the COVID-19 epidemic, many companies and small firms are losing money, suffering due to rising expenses, and their liquid capital reserves are quickly diminishing [144]. SMEs are already confronting a broad range of issues during the COVID-19 epidemic, including job loss, closure of firms, a decline in the number of small enterprises, and a host of other difficulties. Small- and medium-sized enterprises are disadvantaged all around the world.

SME contribution accounts for $45 \%$ of all employment and $40 \%$ on aggregate revenue generation [145]. Scholars such as Schiffer [146], BECK et al. [147], Beck et al. [148], Wasiuzzaman et al. [149], and Engwa, Yakum, and Mukah [120] have suggested that SMEs' ability to participate in economic growth is hindered by their lack of access to financial services, particularly from formal financial institutions. This is due to the owners and managers of SMEs having insufficient financial literacy and more negligible financial services diversification according to SMEs' demand. According to Okello Candiya Bongomin, Mpeera Ntayi, Munene, and Akol Malinga [114], financial literacy via business training leads to developing financial knowledge and business skills required for SMEs to flourish in developing nations. According to Beck, Demirguckunt, and Maksimovic [148], access to credit enables SMEs in emerging countries to make productive investments to expand their operations and acquire cutting-edge technology, assuring their competitiveness and boosting innovation, macroeconomic resilience, and GDP growth. Innovative finance to 
SMEs promotes economic development in the informal sector by encouraging increasing capitalization of businesses, job creation, and long-term income development [150]. Financial innovation allows easy access to financing which increases SMEs performance and growth by making market entrance, risk reduction, and the promotion of innovation easier in emerging countries $[120,151]$.

Technological adaptation opens a new avenue for SMEs as an alternative route for removing COVID-19 by allowing them to reach prospective customers using an online platform [152]. Such beauty of technological integration for SMEs at least opens a hope to survive. E-commerce, social networking, and several other technology platforms may effectively help businesses acquire new customers. The various platforms used for social media include Facebook, Linked In, blogs, Twitter, YouTube, and Instagram; the platforms used for e-commerce include numerous online marketplaces such as Alibaba, Magento, Shopify, and many others, all which employ technology 4.0. Technology 4.0 has emerged as a COVID-19 pandemic solution supplier for small- and medium-sized enterprises (SMEs) for fast processing and reasoning with AI-based algorithms and models [65]. Big data analytics is one method that social networking data may transfer smart manufacturing companies with artificial intelligence [153]. Artificial intelligence-based propensity models and solutions can help in identifying potential customers. The sales managers are in a dilemma in which customers need to be prioritized. The propensity models can help them in prioritizing the customers and, after that, improves sales productivity.

\subsection{Managerial Implications}

The crucial decision about applying and integrating innovative financial products and services in firms' operations has been influenced by two reasons. First, innovative finance integration in operations allows firms easy access to external financing. Second, efficient financial intermediation with prompt financial settlement can be executed with innovative financial services, such as mobile and internet banking. To ensure sustainability in SME operation, the study's implications for the managers, owners, and policymakers are as follows.

The role of innovative financial services and products for SMEs sustainability have circulated among SMEs through arranging workshops, seminars, and training sessions. It is essential to transform SMEs' perception regarding the fear of embracing innovative financial services. The advantages and benefits of innovative finance in terms of financial efficiency and prompt transaction settlement without physical contact must be established in the minds of managers of SMEs. Furthermore, the misconception of additional cost association with advanced financial services has also been resolved by offering a program to enlighten managers' understanding that innovative finance integration is critical for sustainability.

The relationship between technological adaptation and sustainability has found a positive statistically significant connection, suggesting that SMEs sustainability can be augmented through technology integration in firms' operations. To exploit the maximum benefits from technological advancement in the economy, it is imperative to encourage SMEs to adopt IT quickly. Wastage management, production efficiency, and optimal use of economic resources in SMEs are the critical attributes that can be achieved with IT integration. The study postulates that motivating initiatives including financing for technology procurement, a training program for efficient operation, and strategic supports to SMEs can boost IT adaptation. Furthermore, SMEs' investment in IT development allows a higher degree of competitiveness, thus capitalizing on the competitive benefits from the market economy. Business owners play an essential part in the decision-making process regarding the adoption of new technologies. During COVID-19, owners and managers have recognized that they would not survive if they did not embrace new technologies. As a result, firms seek to implement new technologies as quickly and as feasible as possible, and firms are driven due to the epidemic. 
The government support for SMEs sustainability has documented positive statistical significance in assessing a direct and mediating role. The study postulated that government strategic support augments sustainability prospects and plays an essential role in innovative finance development for SMEs and the scope for technological adaptation in operations. Government activities for nurturing the macro environment such as external credit availability, stable market interest rate, affordable tax rate, and reduced transaction cost may create a favourable environment for fostering SMEs. Furthermore, the government's role in formulating policy guidelines and effective implementation focuses on mitigating SMEs' size effects, indicating that government intervention supports SMEs due to potential economic advantages and the ability to scare resources maximization.

\section{Conclusions}

The impact of COVID-19 is unprecedented, and barely any areas remain untapped. However, small business enterprises have been affected immensely due to inherent limitations. Besides, SMEs have been trying hard to figure out how to eliminate the disadvantageous position and reopen business operations. In the line of SMEs regaining the strength for recovery, the government has initiated financial assistance and policy support, such as credit time extension, low margin credit plan, and institutional arrangement. Furthermore, SMEs' sustainability during the pandemic also subsidizes the firms' state of technological integration and practices of financial settlement. This study aims to enlighten government support for SMEs' survival with technological adaptation and innovative finance applications. Findings suggest that the study's motivation is to explore the impact of technological adaptation and innovative finance on SMEs during the pandemic, providing government assistance availability.

Study findings document that technological adaptation and innovative finance application plays a critical role in SME operations during the pandemic. It implies that technologically integrated and sound SMEs have flexible operations working with remote places. Cost-efficiency operations allow them to remain untapped during the pandemic. An e-commerce application that integrates M-banking is one platform with the highest flexibility and efficiency for settling financial transactions without physical appearance. During the lockdown state, SMEs in the path of e-commerce integration maintained their supplier-customer relationship with an efficient financial settlement. Technology can help SMEs overcome numerous issues they may experience during COVID-19. Physical contact, forecasting demand, improving overall sales and turnover, market access, and turning them into profitability are all helped by the many components of technology adoption. Until recently, enterprises could not communicate with long-distance clients. Due to the internet and other e-commerce resources that are now changing and transforming small and medium enterprises with the born global concept integration. Many traditional brickand-mortar office buildings are no longer needed because the internet and e-commerce have given us virtual technical offices that serve small- and medium-sized businesses. The owner should encourage employees to use technology to improve both financial and non-financial results. To cope with the current pandemic, employees will understand the importance of technology adoption. Only technology can assist a business's ongoing operations during a pandemic [153].

For SMEs, the government's financial and policy assistance support during the pandemic is a motivational factor for believing that they will remove this unexpected situation in the coming days. During the initial lockdown, government support, especially financial assistance, worked intensively and motived them to cooperate for countrywide lockdown. Financial help from the government ingrained a belief among SMEs that government support will remain available in the future. That is why SME owners think positively and reopen their operation after lockdown, with optimistic hope.

Furthermore, a critical finding from this research is that technical know-how and financial efficiency have a deterministic role in SMEs' survival. As a result, the government's long-term support for SMEs should be expanded, and SMEs should be encouraged 
to invest in sustainable technologies. Furthermore, government policies that focus on SMEs must pay special attention to technological adaptations and encourage them to use e-commerce banking for financial settlements, containing essential elements.

Author Contributions: Conceptualization, G.P. and M.Q.; data curation, G.P. and M.Q.; formal analysis, A.M.M. and S.K.; funding acquisition, M.Q.; methodology, G.P. and F.N.N.; Writingoriginal draft, M.Q., A.M.M., F.N.N. and S.K.; writing—review \& editing, G.P., M.Q., F.N.N. and S.K. All authors have read and agreed to the published version of the manuscript.

Funding: This research received no external funding.

Institutional Review Board Statement: Not applicable.

Informed Consent Statement: Not applicable.

Data Availability Statement: The data presented in this study are available on request from the corresponding author.

Acknowledgments: We would like to thank three anonymous reviewers for the critical and constructive suggestions, and thus we revised and reconstructed the entire manuscript. Furthermore, we are also grateful to the editor-in-chief and assistant editor for their kind consideration during the revision process.

Conflicts of Interest: The authors declare no conflict of interest.

\section{References}

1. Sansa, N.A. The Impact of the COVID-19 on the Financial Markets: Evidence from China and USA. Electron. Res. J. Soc. Sci. Humanit. 2020, 2. Available online: https:/ / ssrn.com/abstract=3567901 (accessed on 15 February 2021). [CrossRef]

2. Ruiz Estrada, M.A.; Koutronas, E.; Lee, M. Stagpression: The economic and financial impact of Covid-19 Pandemic. Contemp. Econ. 2021, 15, 19-33. [CrossRef]

3. McCloskey, B.; Heymann, D.L. SARS to novel coronavirus-Old lessons and new lessons. Epidemiol. Infect. 2020, 148. [CrossRef] [PubMed]

4. Puriwat, W.; Tripopsakul, S. Customer Engagement with Digital Social Responsibility in Social Media: A Case Study of COVID-19 Situation in Thailand. J. Asian Financ. Econ. Bus. 2021, 8, 475-483.

5. Runyan, R.C. Small business in the face of crisis: Identifying barriers to recovery from a natural disaster 1. J. Contingencies Crisis Manag. 2006, 14, 12-26. [CrossRef]

6. Le, H.; Nguyen, T.; Ngo, C.; Pham, T.; Le, T. Policy related factors affecting the survival and development of SMEs in the context of Covid 19 pandemic. Manag. Sci. Lett. 2020, 10, 3683-3692. [CrossRef]

7. Nseobot, I.R.; Simeon, I.I.; Effiong, A.I.; Frank, E.I.; Ukpong, E.S.; Essien, M.O. COVID-19: The aftermath for businesses in developing countries. Int. J. Bus. Educ. Manag. Stud. 2020. Available online: https://ssrn.com/abstract=3592603 (accessed on 15 February 2021).

8. Fernandes, N. Economic Effects of Coronavirus Outbreak (COVID-19) on the World Economy. IESE Business School Working Paper No. WP-1240-E. Available online: https: / /ssrn.com/abstract=3557504 (accessed on 15 February 2021).

9. Gregurec, I.; Tomičić Furjan, M.; Tomičić-Pupek, K. The impact of COVID-19 on sustainable business models in SMEs. Sustainability 2021, 13, 1098. [CrossRef]

10. Bretas, V.P.G.; Alon, I. The impact of COVID-19 on franchising in emerging markets: An example from Brazil. Glob. Bus. Organ. Excell. 2020, 39, 6-16. [CrossRef]

11. Kuckertz, A.; Brändle, L.; Gaudig, A.; Hinderer, S.; Morales Reyes, C.A.; Prochotta, A.; Steinbrink, K.M.; Berger, E.S.C. Startups in times of crisis-A rapid response to the COVID-19 pandemic. J. Bus. Ventur. Insights 2020, 13, e00169. [CrossRef]

12. Emejulu, G.; Agbasi, O.; Nosike, C. Strategic agility and performance of small and medium enterprises in the phase of Covid-19 pandemic. Int. J. Financ. Account. Manag. 2020, 2, 41-50. [CrossRef]

13. Hadi, S.; Supardi, S. Revitalization strategy for small and medium enterprises after Corona virus disease pandemic (covid-19) in Yogyakarta. J. Xian Univ. Archit. Technol. 2020, 12, 4068-4076.

14. Nyanga, T.; Zirima, H. Reactions of small to medium enterprises in masvingo, Zimbabwe to covid 19: Implications on productivity. Bus. Excell. Manag. 2020, 10, 22-32. [CrossRef]

15. McGeever, N.; McQuinn, J.; Myers, S. SME Liquidity Needs during the COVID-19 Shock. Financial Stability Notes 2/FS/20, Central Bank of Ireland. 2020. Available online: https://www.centralbank.ie/docs/default-source/publications/financialstability-notes /no-2-sme-liquidity-needs-during-the-covid-19-shock-(mcgeever-mcquinn-and-myers).pdf?sfvrsn=6 (accessed on 12 October 2020).

16. Ratnasingam, J.; Khoo, A.; Jegathesan, N.; Wei, L.C.; Abd Latib, H.; Thanasegaran, G.; Liat, L.C.; Yi, L.Y.; Othman, K.; Amir, M.A. How are small and medium enterprises in Malaysia's furniture industry coping with COVID-19 pandemic? Early evidences from a survey and recommendations for policymakers. BioResources 2020, 15, 5951-5964. [CrossRef] 
17. Liguori, E.W.; Pittz, T.G. Strategies for small business: Surviving and thriving in the era of COVID-19. J. Int. Counc. Small Bus. 2020, 1, 106-110. [CrossRef]

18. Fitriasari, F. How do Small and Medium Enterprise (SME) survive the COVID-19 outbreak? J. Inov. Ekon. 2020, 5, 53-62.

19. Saidu, M.; Aifuwa, H.O. Coronavirus Pandemic in Nigeria: How Can Small and Medium Enterprises (SMEs) Cope and Flatten the Curve. Musa S Aifuwa HO (2020). Coronavirus Pandemic Niger. How Can S Small Medium Enterp. SMEs Cope Flatten Curve. Eur. J. Account. Financ. Invest. 2020, 6, 55-61.

20. Manyati, T.K.; Mutsau, M. Exploring technological adaptation in the informal economy: A case study of innovations in small and medium enterprises (SMEs) in Zimbabwe. Afr. J. Sci. Technol. Innov. Dev. 2019, 11, 253-259. [CrossRef]

21. Das, S.; Kundu, A.; Bhattacharya, A. Technology Adaptation and Survival of SMEs: A Longitudinal Study of Developing Countries. Technol. Innov. Manag. Rev. 2020, 10, 64-72. [CrossRef]

22. McGuinness, G.; Hogan, T.; Powell, R. European trade credit use and SME survival. J. Corp. Financ. 2018, 49, 81-103. [CrossRef]

23. Mocking, R.; Möhlmann, J.; Palali, A. Dependence on External Finance and SME Survival. CPB Neth. Bur. Econ. Policy Anal. 2016, $6,12-85$.

24. Ryandono, M.N.H.; Muafi, M.; Guritno, A. Sharia Stock Reaction Against COVID-19 Pandemic: Evidence from Indonesian Capital Markets. J. Asian Financ. Econ. Bus. 2021, 8, 697-710.

25. Brumagim, A.L. A hierarchy of corporate resources. Adv. Strateg. Manag. 1994, 10, 81-112.

26. Penrose, E.T. Tiie Theory of the Growth of the Firm; Oxford University Press: New York, NY, USA, 1959.

27. Lichtenstein, B.M.B.; Brush, C.G. How Do “Resource Bundles" Develop and Change in New Ventures? A Dynamic Model and Longitudinal Exploration. Entrep. Theory Pract. 2001, 25, 37-58. [CrossRef]

28. Adeola, O.; Gyimah, P.; Appiah, K.O.; Lussier, R.N. Can critical success factors of small businesses in emerging markets advance UN Sustainable Development Goals? World J. Entrep. Manag. Sustain. Dev. 2021, 17, 85-105. [CrossRef]

29. Yang, T.; Hughes, K.D.; Zhao, W. Resource combination activities and new venture growth: Exploring the role of effectuation, causation, and entrepreneurs' gender. J. Small Bus. Manag. 2020, 4, 1-29. [CrossRef]

30. Amit, R.; Schoemaker, P.J.H. Strategic assets and organizational rent. Strateg. Manag. J. 1993, 14, 33-46. [CrossRef]

31. Mikalef, P.; Gupta, M. Artificial intelligence capability: Conceptualization, measurement calibration, and empirical study on its impact on organizational creativity and firm performance. Inf. Manag. 2021, 58, 103434. [CrossRef]

32. Brush, C.G.; Greene, P.G.; Hart, M.M. From initial idea to unique advantage: The entrepreneurial challenge of constructing a resource base. Acad. Manag. Perspect. 2001, 15, 64-78. [CrossRef]

33. Wiklund, J.; Shepherd, D. Entrepreneurial orientation and small business performance: A configurational approach. J. Bus. Ventur. 2005, 20, 71-91. [CrossRef]

34. Rindova, V.P.; Yeow, A.; Martins, L.L.; Faraj, S. Partnering portfolios, value-creation logics, and growth trajectories: A comparison of Yahoo and Google (1995 to 2007). Strateg. Entrep. J. 2012, 6, 133-151. [CrossRef]

35. Wang, Y.; Hong, A.; Li, X.; Gao, J. Marketing innovations during a global crisis: A study of China firms' response to COVID-19. J. Bus. Res. 2020, 116, 214-220. [CrossRef]

36. Barney, J.B.; Arikan, A.M. The resource-based view: Origins and implications. Blackwell Handb. Strateg. Manag. 2001, 5, 124-188.

37. Cowling, M.; Liu, W.; Ledger, A.; Zhang, N. What really happens to small and medium-sized enterprises in a global economic recession? UK evidence on sales and job dynamics. Int. Small Bus. J. 2015, 33, 488-513. [CrossRef]

38. Nason, R.S.; Wiklund, J. An Assessment of Resource-Based Theorizing on Firm Growth and Suggestions for the Future. J. Manag. 2015, 44, 32-60. [CrossRef]

39. Joseph, J.; Wilson, A.J. The growth of the firm: An attention-based view. Strateg. Manag. J. 2018, 39, 1779-1800. [CrossRef]

40. Barney, J.; Wright, M.; Ketchen, D.J., Jr. The resource-based view of the firm: Ten years after 1991. J. Manag. 2001, $27,625-641$. [CrossRef]

41. Brinckmann, J.; Salomo, S.; Gemuenden, H.G. Financial Management Competence of Founding Teams and Growth of New Technology-Based Firms. Entrep. Theory Pract. 2011, 35, 217-243. [CrossRef]

42. Brown, R.; Rocha, A.; Cowling, M. Financing entrepreneurship in times of crisis: Exploring the impact of COVID-19 on the market for entrepreneurial finance in the United Kingdom. Int. Small Bus. J. 2020, 38, 380-390. [CrossRef]

43. Weaven, S.; Quach, S.; Thaichon, P.; Frazer, L.; Billot, K.; Grace, D. Surviving an economic downturn: Dynamic capabilities of SMEs. J. Bus. Res. 2021, 128, 109-123. [CrossRef]

44. Barney, J.B. Resource-based theories of competitive advantage: A ten-year retrospective on the resource-based view. J. Manag. 2001, 27, 643-650. [CrossRef]

45. Calabrò, A.; Torchia, M.; Jimenez, D.G.; Kraus, S. The role of human capital on family firm innovativeness: The strategic leadership role of family board members. Int. Entrep. Manag. J. 2021, 17, 261-287. [CrossRef]

46. Wapshott, R.; Mallett, O. Managing Human Resources in Small and Medium-Sized Enterprises: Entrepreneurship and the Employment Relationship; Routledge: London, UK, 2015.

47. Harney, B.; Alkhalaf, H. A quarter-century review of HRM in small and medium-sized enterprises: Capturing what we know, exploring where we need to go. Hum. Resour. Manag. 2021, 60, 5-29. [CrossRef]

48. Kor, Y.Y.; Mahoney, J.T. Penrose's Resource-Based Approach: The Process and Product of Research Creativity. J. Manag. Stud. 2000, 37. [CrossRef] 
49. Watson, W.; Stewart, W.H.; BarNir, A. The effects of human capital, organizational demography, and interpersonal processes on venture partner perceptions of firm profit and growth. J. Bus. Ventur. 2003, 18, 145-164. [CrossRef]

50. von Krogh, G. Building Capacity for Empirical Discovering in Management and Organization Studies. Acad. Manag. Discov. 2020, 6, 159-164. [CrossRef]

51. Shang, Y.; Li, H.; Zhang, R. Effects of Pandemic Outbreak on Economies: Evidence From Business History Context. Front. Public Health 2021, 9, 1-12. [CrossRef]

52. Ojong-Ejoh, M.U.; Angioha, P.U.; Agba, R.U.; Aniah, E.A.; Salimon, M.G.; Akintola, A. Operating SMEs in the Face of the Covid-19 Pandemic in Calabar. Quant. Econ. Manag. Stud. 2021, 2, 272-280. [CrossRef]

53. Popovic, J.; Kvrgic, G.; Coric, G.; Avakumovic, J.; Milosevic, D. Uncertainty in Smes'assessment of Coronavirus Pandemic Risk Impact on Agri-Food Sector in Western Balkans. Економика Noљопривреде 2020, 67, 25-41.

54. Miocevic, D. Investigating strategic responses of SMEs during COVID-19 pandemic: A cognitive appraisal perspective. BRQ Bus. Res. Q. 2021, 12, 1-40.

55. Aidoo, S.O.; Agyapong, A.; Acquaah, M.; Akomea, S.Y. The performance implications of strategic responses of SMEs to the covid-19 pandemic: Evidence from an African economy. Afr. J. Manag. 2021, 7, 74-103. [CrossRef]

56. Li, Z.; Anaba, O.A.; Ma, Z.; Li, M. Ghanaian SMEs Amidst the COVID-19 Pandemic: Evaluating the Influence of Entrepreneurial Orientation. Sustainability 2021, 13, 1131. [CrossRef]

57. Amankwah-Amoah, J.; Khan, Z.; Wood, G. COVID-19 and business failures: The paradoxes of experience, scale, and scope for theory and practice. Eur. Manag. J. 2021, 39, 179-184. [CrossRef]

58. Dzingirai, M.; Tshuma, N.; Sikomwe, S. Post-Pandemic Sustainability Strategies for Zimbabwean SMEs. In Handbook of Research on Strategies and Interventions to Mitigate COVID-19 Impact on SMEs; IGI Global: Hershey, PA, USA, 2021; pp. 457-476.

59. Elshenawi, D.M.; Wang, Y. How to protect factory workers from COVID-19? BioResources 2020, 15, 7315-7318. [CrossRef]

60. Beraha, I.; Đuričin, S. The Impact of COVID-19 Crisis on Medium-sized Enterprises in Serbia. Econ. Anal. 2020, 53, 14-27.

61. Robinson, J.; Kengatharan, N. Exploring the effect of Covid-19 on Small and Medium Enterprises: Early Evidence from Sri Lanka. J. Appl. Econ. Bus. Res. 2020, 10, 115-125.

62. Lu, Y.; Wu, J.; Peng, J.; Lu, L. The perceived impact of the Covid-19 epidemic: Evidence from a sample of 4807 SMEs in Sichuan Province, China. Environ. Hazards 2020, 19, 323-340. [CrossRef]

63. Garba, A. Effect of covid 19 on small and medium scale enterpriss performance in Makurdi Metropolis, Benue State, Nigeria. GRA's Multidiscip. Int. GRAM I J. 2020, 4, 25-45.

64. Omar, A.R.C.; Ishak, S.; Jusoh, M.A. The impact of Covid-19 Movement Control Order on SMEs' businesses and survival strategies. Geogr. Malays. J. Soc. Space 2020, 16, 1-22.

65. Akpan, I.J.; Udoh, E.A.P.; Adebisi, B. Small business awareness and adoption of state-of-the-art technologies in emerging and developing markets, and lessons from the COVID-19 pandemic. J. Small Bus. Entrep. 2020, 6, 1-18. [CrossRef]

66. Fitriyani, I.; Sudiyarti, N.; Fietroh, M.N. Strategi Manajemen Bisnis Pasca Pandemi Covid-19. Indones. J. Soc. Sci. Humanit. 2020, 1, 87-95.

67. Khan, S.; Hassan, M.K.; Rabbani, M.R.; Atif, M. An artificial intelligence-based Islamic FinTech model on Qardh-Al-Hasan for COVID 19 affected SMEs. In Islamic Perspective for Sustainable Financial System; Istanbul University Press: Istanbul, Turkey, 2021.

68. Zimon, G.; Dankiewicz, R. Trade Credit Management Strategies in SMEs and the COVID-19 Pandemic-A Case of Poland. Sustainability 2020, 12, 6114. [CrossRef]

69. Islam, A.; Jerin, I.; Hafiz, N.; Nimfa, D.T.; Wahab, S.A. Configuring a blueprint for Malaysian SMEs to survive through the COVID-19 crisis: The reinforcement of Quadruple Helix Innovation Model. J. Entrep. Bus. Econ. 2021, 9, 32-81.

70. Kukanja, M.; Planinc, T.; Sikošek, M. Crisis Management Practices in Tourism SMEs During the Covid-19 Pandemic. Organizacija 2020, 53, 27-35. [CrossRef]

71. Islam, M.A.; Igwe, P.A.; Rahman, M.; Saif, A.N.M. Remote working challenges and solutions: Insights from SMEs in Bangladesh during the COVID-19 pandemic. Int. J. Qual. Innov. 2020.

72. Syriopoulos, K. The impact of COVID-19 on entrepreneurship and SMEs. J. Int. Acad. Case Stud. 2020, $26,1-2$.

73. Chowdhury, M.T.; Sarkar, A.; Paul, S.K.; Moktadir, M.A. A case study on strategies to deal with the impacts of COVID-19 pandemic in the food and beverage industry. Oper. Manag. Res. 2020. [CrossRef]

74. Raimi, L.; Uzodinma, I. Trends in Financing Programmes for the Development of Micro, Small and Medium Enterprises (MSMEs) in Nigeria: A Qualitative Meta-synthesis. In Contemporary Developments in Entrepreneurial Finance; Springer: Berlin/Heidelberg, Germany, 2020; pp. 81-101.

75. Popon, S.; Muhammad Iqbal, F.; Sri, N.; Anugrahwanto, R.B.; Ahmad Wahyu, H.; Deddy, S.; Anggi, F.; Siti, R.; Dwi Noviatul, Z. The Nexus Between Dynamic Capability and Islamic Financial Literacy Towards Innovation of Small Medium Enterprises (SMEs) in Indonesia. In Proceedings of the 1st Paris Van Java International Seminar on Health, Economics, Social Science and Humanities (PVJ-ISHESSH 2020), Paris, France, 8 March 2021; Atlantis Press: Amsterdam, The Netherlands; pp. 36-39.

76. Kabanda, S.; Brown, I. A structuration analysis of Small and Medium Enterprise (SME) adoption of E-Commerce: The case of Tanzania. Telemat. Inform. 2017, 34, 118-132. [CrossRef]

77. Muchiri, J.W. Effect of mobile banking adoption on the performance of small and medium enterprises in Nairobi County. Int. J. Econ. Bus. Manag. 2018, 2, 445-486.

78. Clarke, R. Risks inherent in the digital surveillance economy: A research agenda. J. Inf. Technol. 2019, 34, 59-80. [CrossRef] 
79. Barati, S.; Mohammadi, S. An efficient model to improve customer acceptance of mobile banking. In Proceedings of the World Congress on Engineering and Computer Science, San Francisco, CA, USA, 20-22 October 2009; pp. $20-22$.

80. Ibrahim, E.E.; Joseph, M.; Ibeh, K.I. Customers' perception of electronic service delivery in the UK retail banking sector. Int. J. Bank Mark. 2006, 24, 475-493. [CrossRef]

81. Evangelista, P.; McKinnon, A.; Sweeney, E. Technology adoption in small and medium-sized logistics providers. Ind. Manag. Data Syst. 2013, 113, 967-989. [CrossRef]

82. ERIND, H. He technological, organizational and environmental framework of IS innovation adaption in small and medium enterprises. Evidence from research over the last 10 years. Int. Ournal Bus. Manag. 2015, 3, 1-14.

83. Lee, H.; Kelley, D.; Lee, J.; Lee, S. SME Survival: The Impact of Internationalization, Technology Resources, and Alliances. J. Small Bus. Manag. 2012, 50,1-19. [CrossRef]

84. Windrum, P.; De Berranger, P. The Adoption of E-Business Technology by SMEs; Maastricht Economic Research Institute on Innovation and Technology: Maastricht, The Netherlands, 2002.

85. Quaddus, M.; Hofmeyer, G. An investigation into the factors influencing the adoption of B2B trading exchanges in small businesses. Eur. J. Inf. Syst. 2007, 16, 202-215. [CrossRef]

86. Esselaar, P.; Miller, J. Towards electronic commerce in Africa: A perspective from three country studies. South. Afr. J. Inf. Commun. 2001, 2001, 1-19. [CrossRef]

87. Hanadi, A.; Aruna, M. Technology innovation for SME growth: A perception for the emerging economies. Technology 2013, 4, 156-162.

88. Cassiman, B.; Veugelers, R. R\&D cooperation and spillovers: Some empirical evidence from Belgium. Am. Econ. Rev. 2002, 92, 1169-1184.

89. Tiwari, M. Competitiveness of SMEs through different strategies. IOSR J. Bus. Manag 2014, 16, 63-68. [CrossRef]

90. Myers, S.; Majiuf, N. Corporate financing and investment decisions when firms have information that investors do not have. $J$. Financ. Econ. 1984, 25, 187-220. [CrossRef]

91. Storey, D.J.; Tether, B.S. Public policy measures to support new technology-based firms in the European Union. Res. Policy 1998, 26, 1037-1057. [CrossRef]

92. Ganotakis, P.; D'Angelo, A.; Konara, P. From latent to emergent entrepreneurship: The role of human capital in entrepreneurial founding teams and the effect of external knowledge spillovers for technology adoption. Technol. Forecast. Soc. Chang. 2021, 170, 120912. [CrossRef]

93. Burt, R.S. The Network Structure Of Social Capital. Res. Organ. Behav. 2000, 22, 345-423. [CrossRef]

94. Barney, J. Firm resources and sustained competitive advantage. J. Manag. 1991, 17, 99-120. [CrossRef]

95. Sheng, S.; Zhou, K.Z.; Li, J.J. The Effects of Business and Political Ties on Firm Performance: Evidence from China. J. Mark. 2011, 75, 1-15. [CrossRef]

96. Wei, J.; Liu, Y. Government support and firm innovation performance. Chin. Manag. Stud. 2015, 9, 38-55. [CrossRef]

97. Clement, K.; Hansen, M. Financial incentives to improve environmental performance: A review of Nordic public sector support for SMEs. Eur. Environ. 2003, 13, 34-47. [CrossRef]

98. Wu, W.; Wu, C.; Zhou, C.; Wu, J. Political connections, tax benefits and firm performance: Evidence from China. J. Account. Public Policy 2012, 31, 277-300. [CrossRef]

99. Li, H.; Meng, L.; Wang, Q.; Zhou, L.-A. Political connections, financing and firm performance: Evidence from Chinese private firms. J. Dev. Econ. 2008, 87, 283-299. [CrossRef]

100. Guariglia, A.; Liu, X.; Song, L. Internal finance and growth: Microeconometric evidence on Chinese firms. J. Dev. Econ. 2011, 96, 79-94. [CrossRef]

101. Loader, K. Supporting SMEs through government purchasing activity. Int. J. Entrep. Innov. 2005, 6, 17-26. [CrossRef]

102. Smallbone, D.; Welter, F. The role of government in SME development in transition economies. Int. Small Bus. J. 2001, 19, 63-77. [CrossRef]

103. Arshad, M.; Arshad, D. Internal capabilities and SMEs performance: A case of textile industry in Pakistan. Manag. Sci. Lett. 2019, 9, 621-628. [CrossRef]

104. Fosfuri, A.; Tribó, J.A. Exploring the antecedents of potential absorptive capacity and its impact on innovation performance. Omega 2008, 36, 173-187. [CrossRef]

105. Arshad, M.; Ahmad, M.; Ali, M.; Khan, W.; Arshad, M. The role of government business support services and absorptive capacity on SMES performance. Int. J. Adv. Sci. Technol. 2020, 29, 1492-1499.

106. Teixeira, A.A.; Jabbour, C.J.C.; de Sousa Jabbour, A.B.L. Relationship between green management and environmental training in companies located in Brazil: A theoretical framework and case studies. Int. J. Prod. Econ. 2012, 140, 318-329. [CrossRef]

107. Lin, H.-F. Understanding the determinants of electronic supply chain management system adoption: Using the technologyorganization-environment framework. Technol. Forecast. Soc. Chang. 2014, 86, 80-92. [CrossRef]

108. Razumovskaia, E.; Yuzvovich, L.; Kniazeva, E.; Klimenko, M.; Shelyakin, V. The Effectiveness of Russian Government Policy to Support SMEs in the COVID-19 Pandemic. J. Open Innov. Technol. Mark. Complex. 2020, 6, 160. [CrossRef]

109. Prasanna, R.; Jayasundara, J.; Naradda Gamage, S.K.; Ekanayake, E.; Rajapakshe, P.; Abeyrathne, G. Sustainability of smes in the competition: A systemic review on technological challenges and sme performance. J. Open Innov. Technol. Mark. Complex. 2019, 5, 100. [CrossRef] 
110. Robson, C.; McCartan, K. Real World Research; John Wiley \& Sons: New York, NY, USA, 2016.

111. Meng, L.; Qamruzzaman, M.; Adow, A.H.E. Technological Adaption and Open Innovation in SMEs: An Strategic Assessment for Women-Owned SMEs Sustainability in Bangladesh. Sustainability 2021, 13, 2942. [CrossRef]

112. Ye, J.; Kulathunga, K. How does financial literacy promote sustainability in SMEs? A developing country perspective. Sustainability 2019, 11, 2990. [CrossRef]

113. Ardic, O.P.; Mylenko, N.; Saltane, V. Access to Finance by Small and Medium Enterprises: A Cross-Country Analysis with A New Data Set. Pac. Econ. Rev. 2012, 17, 491-513. [CrossRef]

114. Okello Candiya Bongomin, G.; Mpeera Ntayi, J.; Munene, J.C.; Akol Malinga, C. The relationship between access to finance and growth of SMEs in developing economies. Rev. Int. Bus. Strategy 2017, 27, 520-538. [CrossRef]

115. Alkahtani, A.; Nordin, N.; Khan, R.U. Does government support enhance the relation between networking structure and sustainable competitive performance among SMEs? J. Innov. Entrep. 2020, 9, 14. [CrossRef]

116. Zamberi Ahmad, S.; Xavier, S.R. Entrepreneurial environments and growth: Evidence from Malaysia GEM data. J. Chin. Entrep. 2012, 4, 50-69. [CrossRef]

117. Ying, Q.; Hassan, H.; Ahmad, H. The Role of a Manager's Intangible Capabilities in Resource Acquisition and Sustainable Competitive Performance. Sustainability 2019, 11, 527. [CrossRef]

118. Eniola, A.A.; Entebang, H. SME Firm Performance-Financial Innovation and Challenges. Procedia Soc. Behav. Sci. 2015, 195, 334-342. [CrossRef]

119. Qamruzzaman, M.; Wei, J. Financial innovation and financial inclusion nexus in South Asian countries: Evidence from symmetric and asymmetric panel investigation. Int. J. Financ. Stud. 2019, 7, 61. [CrossRef]

120. Engwa, F.E.; Yakum, I.M.; Mukah, S.T. The Role of Banking Institutional Services on the Sustainable growth of SMEs in Cameroon. J. Econ. Manag. Sci. 2021, 4, 1-14.

121. Muneeb, M.A.; Asad, A.L.I.; Hina, S.; Md, Q.; Rimsha, K. The Effect of Technology and Open Innovation on Women-Owned Small and Medium Enterprises in Pakistan. J. Asian Financ. Econ. Bus. 2021, 8, 411-422. [CrossRef]

122. Chigozie, M.P.; Ifeanyi, E.R.; Irenaus, O.N. Technology Adaptation Strategies By Smes In Nigeria. Econspeak A J. Adv. Manag. IT Soc. Sci. 2016, 6, 49-61.

123. Peter, F.; Adegbuyi, O.; Olokundun, M.; Peter, A.O.; Amaihian, A.B.; Ibidunni, A.S. Government financial support and financial performance of SMEs. Acad. Strateg. Manag. J. 2018, 17, 1-10.

124. Lamoureux, S.M.; Movassaghi, H.; Kasiri, N. The role of government support in SMEs' adoption of sustainability. IEEE Eng. Manag. Rev. 2019, 47, 110-114. [CrossRef]

125. Loehlin, J.C. Latent Variable Models: An Introduction to Factor, Path, and Structural Equation Analysis; Psychology Press: New York, NY, USA, 2004.

126. Steenkamp, J.-B.E.M.; Baumgartner, H. On the use of structural equation models for marketing modeling. Int. J. Res. Mark. 2000, 17, 195-202. [CrossRef]

127. Lei, P.-W.; Wu, Q. Introduction to Structural Equation Modeling: Issues and Practical Considerations. Educ. Meas. Issues Pract. 2007, 26, 33-43. [CrossRef]

128. Bagozzi, R.P. A Holistic Methodology for Modeling Consumer Response to Innovation. Oper. Res. 1983, 31, 128-176. [CrossRef] [PubMed]

129. Neale, M.C.; Hunter, M.D.; Pritikin, J.N.; Zahery, M.; Brick, T.R.; Kirkpatrick, R.M.; Estabrook, R.; Bates, T.C.; Maes, H.H.; Boker, S.M. OpenMx 2.0: Extended Structural Equation and Statistical Modeling. Psychometrika 2016, 81, 535-549. [CrossRef]

130. Al-Gahtani, S.S. Empirical investigation of e-learning acceptance and assimilation: A structural equation model. Appl. Comput. Inform. 2016, 12, 27-50. [CrossRef]

131. Tajdini, S. The effects of the subjective-experiential knowledge gap on consumers' information search behavior and perceptions of consumption risk. J. Bus. Res. 2021, 135, 66-77. [CrossRef]

132. Masukujjaman, M.; Alam, S.S.; Siwar, C.; Halim, S.A. Purchase intention of renewable energy technology in rural areas in Bangladesh: Empirical evidence. Renew. Energy 2021, 170, 639-651. [CrossRef]

133. Curran, P.J.; West, S.G.; Finch, J.F. The robustness of test statistics to nonnormality and specification error in confirmatory factor analysis. Psychol. Methods 1996, 1, 16. [CrossRef]

134. Hair, J.F., Jr.; Hult, G.T.M.; Ringle, C.; Sarstedt, M. A Primer on Partial Least Squares Structural Equation Modeling (PLS-SEM); Springer International Publishing AG: New York, NY, USA, 2017.

135. Sarstedt, M.; Hair, J.F., Jr.; Cheah, J.-H.; Becker, J.-M.; Ringle, C.M. How to specify, estimate, and validate higher-order constructs in PLS-SEM. Australas. Mark. J. 2019, 27, 197-211. [CrossRef]

136. Fornell, C.; Larcker, D.F. Structural equation models with unobservable variables and measurement error: Algebra and statistics. J. Mark. Res. 1981, 18, 382-388. [CrossRef]

137. Henseler, J.; Ringle, C.M.; Sarstedt, M. A new criterion for assessing discriminant validity in variance-based structural equation modeling. J. Acad. Mark. Sci. 2015, 43, 115-135. [CrossRef]

138. Yusoff, A.S.M.; Peng, F.S.; Abd Razak, F.Z.; Mustafa, W.A. Discriminant Validity Assessment of Religious Teacher Acceptance: The Use of HTMT Criterion. J. Phys. Conf. Ser. 2020, 1529, 042045. [CrossRef]

139. Ab Hamid, M.; Sami, W.; Sidek, M.M. Discriminant validity assessment: Use of Fornell \& Larcker criterion versus HTMT criterion. J. Phys. Conf. Ser. 2017, 890, 012163. 
140. Voorhees, C.M.; Brady, M.K.; Calantone, R.; Ramirez, E. Discriminant validity testing in marketing: An analysis, causes for concern, and proposed remedies. J. Acad. Mark. Sci. 2016, 44, 119-134. [CrossRef]

141. Arbuckle, J. IBM SPSS Amos 20 User's Guide; Amos Development, SPSS: Chicago, IL, USA, 2011.

142. Manimala, M.J.; Vijay, D. Technology Business Incubators (TBIs): A Perspective for the Emerging Economies. IIM Bangalore Research Paper. 2012. Available online: https:/ / ssrn.com/abstract=2117720 (accessed on 15 February 2021).

143. Drucker, P.F. The theory of the business. Harward Bus. Rev. 1994, 72, 95-104.

144. Singh, R.K.; Kumar, R. Strategic issues in supply chain management of Indian SMEs due to globalization: An empirical study. Benchmarking Int. J. 2020, 27, 913-932. [CrossRef]

145. Abor, Q. Issues in SME Development in Ghana and South Africa. Int. Res. J. Financ. Econ. 2010, 19, $218-228$.

146. Schiffer, M.; Weder di Mauro, B. Firm Size and the Business Environment. 2001. Available online: https://openknowledge. worldbank.org/handle/10986/13988 (accessed on 15 February 2021).

147. Beck, T.; Demirgüç-Kunt, A.; Maksimovic, V. Financial and Legal Constraints to Growth: Does Firm Size Matter? J. Financ. 2005, 60, 137-177. [CrossRef]

148. Beck, T.; Demirguckunt, A.; Maksimovic, V. Financing patterns around the world: Are small firms different? J. Financ. Econ. 2008, 89, 467-487. [CrossRef]

149. Wasiuzzaman, S.; Nurdin, N.; Abdullah, A.H.; Vinayan, G. Creditworthiness and access to finance of SMEs in Malaysia: Do linkages with large firms matter? J. Small Bus. Enterp. Dev. 2020, 27, 197-217. [CrossRef]

150. Kevane, M.; Wydick, B. Microenterprise Lending to Female Entrepreneurs: Sacrificing Economic Growth for Poverty Alleviation? World Dev. 2001, 29, 1225-1236. [CrossRef]

151. Tiwari, A.K.; Shahbaz, M.; Islam, F. Does financial development increase rural-urban income inequality? Int. J. Soc. Econ. 2013, 40, 151-168. [CrossRef]

152. Kumar, A.; Ayedee, D. Technology Adoption: A Solution for SMEs to Overcome Problems during COVID-19. Forthcom. Acad. Mark. Stud. J. 2021, 25, 245-260.

153. Moeuf, A.; Lamouri, S.; Pellerin, R.; Eburdy, R.; Tamayo, S. Industry 4.0 and the SME: A technology-focused review of the empirical literature. In Proceedings of the 7th International Conference on Industrial Engineering and Systems Management IESM, Saarbrücken, Germany, 11-13 October 2017. 